Atmos. Chem. Phys., 18, 15105-15123, 2018

https://doi.org/10.5194/acp-18-15105-2018

(c) Author(s) 2018. This work is distributed under

the Creative Commons Attribution 4.0 License.

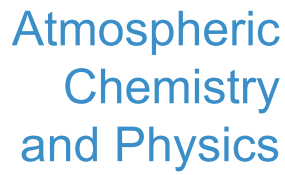

(c) (P)

\title{
The oxidation regime and SOA composition in limonene ozonolysis: roles of different double bonds, radicals, and water
}

\author{
Yiwei Gong, Zhongming Chen, and Huan Li \\ State Key Laboratory of Environmental Simulation and Pollution Control, College of Environmental Sciences \\ and Engineering, Peking University, Beijing 100871, China
}

Correspondence: Zhongming Chen (zmchen@pku.edu.cn)

Received: 11 April 2018 - Discussion started: 14 May 2018

Revised: 30 September 2018 - Accepted: 6 October 2018 - Published: 19 October 2018

\begin{abstract}
Volatile organic compounds play an important role in air quality and climate change, largely because they contribute to the formation of oxidizing compounds and secondary organic aerosol (SOA). In this study, a series of products, including peroxides and carbonyl compounds in both gaseous and particulate phases, were simultaneously detected to investigate the oxidation regime and SOA composition in limonene ozonolysis. The roles of different double bonds (DBs), radicals, and water were also examined. In our first investigation, we focused on representative oxidizing compounds produced in limonene ozonolysis, including stabilized Criegee intermediates (SCIs), $\mathrm{OH}$ radicals, and peroxides. The dependence of $\mathrm{H}_{2} \mathrm{O}_{2}$ and hydroxymethyl hydroperoxide (HMHP) formation on $\mathrm{RH}$ demonstrates that the reaction with water is an important reaction pathway for limonene SCIs, and the lower limit SCI yields of endocyclic and exocyclic DBs were estimated to be $\sim 0.24$ and $\sim 0.43$, respectively. The $\mathrm{OH}$ yield was determined by adding sufficient amounts of an $\mathrm{OH}$ scavenger, and the $\mathrm{OH}$ yields of endocyclic and exocyclic DBs were $\sim 0.65$ and $\sim 0.24$, respectively. These results indicate that in limonene ozonolysis the endocyclic DB is inclined to generate $\mathrm{OH}$ radicals through the hydroperoxide channel, while the exocyclic DB has a higher fraction of forming SCIs. Additionally, other gas-phase and particle-phase peroxides were also studied in this work. The formation of performic acid (PFA) and peracetic acid (PAA) was promoted significantly by increasing $\mathrm{RH}$ and the degree of oxidation, and the discrepancy between the experimental and model results suggested some missing formation pathways. Considerable generation of $\mathrm{H}_{2} \mathrm{O}_{2}$ from SOA in the aqueous phase was observed, especially at a high $\left[\mathrm{O}_{3}\right] /$ [limonene] ratio, which was mainly attributed
\end{abstract}

to the hydration and decomposition of unstable peroxides in SOA such as peroxycarboxylic acids and peroxyhemiacetals. Different DBs and $\mathrm{OH}$ scavengers had a large impact on the particulate peroxides, and their stability indicated that the types of peroxides in SOA changed under different conditions. As for the contribution of peroxides to SOA, the results demonstrated that the mass fraction of particulate peroxides in limonene SOA was less than 0.2 at a low $\left[\mathrm{O}_{3}\right]$ / [limonene] ratio, while the mass fraction was 0.4 0.6 at a high $\left[\mathrm{O}_{3}\right] /$ [limonene] ratio. The partitioning behavior of peroxides showed that multi-generation oxidation helped produce more low-volatility peroxides, which partially explained the higher SOA yield. The partitioning behavior of carbonyls was also examined and the experimental partitioning coefficients $\left(K_{\mathrm{p}}\right)$ were found to be typically several orders of magnitude higher than the theoretical values. This study provided new insights into the oxidation regime and SOA composition in limonene ozonolysis, and limonene showed its specificity in many aspects when both endocyclic and exocyclic DBs were ozonated. We suggest that the atmospheric implications of terpenes containing more than one DB and the SOA composition, especially particulate peroxides, need further study.

\section{Introduction}

As an important monoterpene, limonene has a high emission rate from both biogenic and anthropogenic sources that is second only to pinene (Atkinson and Arey, 2003; Clausen et al., 2001; Fellin and Otson, 1994; Griffin et al., 1999; Guenther et al., 1995; Lamb et al., 1993; Seifert et al., 1989; Sinde- 
larova et al., 2014; Wolkoff et al., 2000). Total monoterpene emissions are estimated to be $50 \mathrm{TgC}^{-1}$, and limonene might comprise about $20 \%$ of that (Stroud et al., 2005). In addition to massive emissions from vegetation, the extensive utilization of limonene in household and industrial processes makes it non-negligible in the atmosphere. Compared with its isomers $\alpha$-pinene and $\beta$-pinene, an obvious structural feature of limonene is that it has two different double bonds (DBs), an endocyclic DB and an exocyclic DB, which complicates the behavior and the fate of limonene in the atmosphere. Ozonolysis is an important reaction pathway of limonene and it serves as a source of free radicals, intermediate products, and aerosol. The first step in alkene ozonolysis is the addition of $\mathrm{O}_{3}$ to the carbon-carbon double bond, forming an energy-rich primary ozonide (POZ). The POZ decomposes into two sets of carbonyls plus carbonyl oxides, which are called excited Criegee intermediates (ECIs) (Criegee, 1975; Fenske et al., 2000; Gutbrod et al., 1996, 1997; Kroll et al., 2001a, b). ECIs can isomerize through the hydroperoxide channel followed by $\mathrm{OH}$ production, rearrange to esters with subsequent decomposition, or undergo collisional stabilization, forming stabilized Criegee intermediates (SCIs) (Cremer et al., 1993; Presto and Donahue, 2004; Richard et al., 1999; Wegener et al., 2007).

In the last few years, the oxidizing compounds formed in alkene ozonolysis have received much attention because they are able to remove a series of trace gases and contribute to atmospheric oxidation capacity (Möller, 2009; Prinn, 2003; Taatjes et al., 2013). Representatives of these compounds include $\mathrm{OH}$ radicals, SCIs, and peroxides, etc. Investigations into the oxidation regime of alkene ozonolysis are essential to understanding of the formation of these critical products and evaluation of the actual impact of this reaction in the atmosphere. As an important source of $\mathrm{OH}$ radicals needed for $\mathrm{OH}$-initiated reactions occurring in darkness (Kroll et al., 2001a, b), OH formation pathways in alkene ozonolysis have been extensively studied and the major pathway is considered to be the unimolecular decomposition of ECIs. Furthermore, some studies suggest that SCIs could also generate $\mathrm{OH}$ radicals through self-decomposition or reactions with other species (Anglada et al., 2002; Hasson et al., 2003; Kroll et al., 2001a, b; Tillmann et al., 2010; Zhang and Zhang, 2005). SCIs generated during the process have been shown to have a lifetime, usually on the order of subseconds (Kroll et al., 2001a, b; Long et al., 2018; Mauldin et al., 2012), that is sufficiently long to react with other trace species, such as $\mathrm{H}_{2} \mathrm{O}, \mathrm{SO}_{2}, \mathrm{NO}_{2}$, carbonyls, alcohols, and carboxylic acids. (Sakamoto et al., 2017; Sipilä et al., 2014; Yao et al., 2014). A number of studies have focused on the reactions of SCIs containing 3 or fewer carbon atoms, and their unimolecular decomposition and reactions with water show strong structure dependence. The reactions with water monomers and water dimers are the main reaction pathways for $\mathrm{CH}_{2} \mathrm{OO}$ and anti- $\mathrm{CH}_{3} \mathrm{CHOO}$, while the unimolecular decomposition would be more important for $\mathrm{syn}-\mathrm{CH}_{3} \mathrm{CHOO}$ and $\left(\mathrm{CH}_{3}\right)_{2} \mathrm{COO}$ (Huang et al., 2015; Lin et al., 2016; Welz et al., 2012, 2014; Taatjes et al., 2013). However, the reaction mechanisms for larger SCIs formed from biogenic alkenes ozonolysis are still unclear, since it is difficult to synthesize and observe them directly. Furthermore, reactions of alkenes with ozone can also generate a considerable amount of peroxides, which are considered to be important due to their oxidizability and role as a radicals' reservoir. $\mathrm{H}_{2} \mathrm{O}_{2}$ is the most crucial oxidant to oxidize $\mathrm{S}$ (IV), forming sulfuric acid and sulfate in the aqueous phase (Calvert et al., 1985; Penkett et al., 1979; Peña et al., 2001). And as a species accounting for $40 \%-50 \%$ of total global organic peroxides (Crounse et al., 2006; Khan et al., 2015), peroxycarboxylic acids $(\mathrm{RC}(\mathrm{O}) \mathrm{OOH})$ play an important role in promoting atmospheric oxidation capacity and enhancing the acidity of the aqueous phase.

One important reason why limonene chemistry has attracted much attention is its high secondary organic aerosol (SOA) formation potential, which is higher than that of $\alpha$ pinene since limonene is doubly unsaturated (AnderssonSköld and Simpson 2001; Kroll and Seinfeld, 2008; Lane et al., 2008; Lee et al., 2006). Although progress has been made in simulating SOA formation with the theory of gasparticle partitioning, there are still large discrepancies between model and experimental results (Cocker et al., 2001; Griffin et al., 1999; Hoffmann et al., 1997; Odum et al., 1996; Pankow, 1994; Presto et al., 2005; Pye and Seinfeld, 2010). Laboratory studies of SOA formation in limonene ozonolysis mainly focused on the aerosol yields under different conditions and the identification of products in the particle phase (Calogirou et al., 1999; Glasius et al., 2000; Grosjean et al., 1992, 1993; Leungsakul et al., 2005; Ng et al., 2006; Pathak et al., 2012); however, the composition of limonene SOA still needs detailed study, especially the effect of different DBs. As a double-unsaturated terpene, the SOA formation process of limonene could be more complicated than that for singleunsaturated terpene, since multi-generation oxidation has a significant influence on SOA. In this study, two classes of species, peroxides and carbonyls, are studied for their behaviors in limonene SOA formation. Over the past few years, analyses of organic peroxides suggest that they are an important component in aerosol (Docherty et al., 2005; Heaton et al., 2007; Li et al., 2016; Mertes et al., 2012; Pathak et al., 2012), and particulate peroxides could cause negative health effects when they penetrate into lungs (Chen et al., 2011; Fischer and Maier, 2015; Gupta et al., 2014; Verma et al., 2009; Wragg et al., 2016). The reactive uptake and particle-phase reactions of carbonyls are believed to be responsible for fractions of aqueous SOA formation (Ervens et al., 2011; Mcneill et al., 2012), especially for the dicarbonyls glyoxal (GL) and methylglyoxal (MGL). Until now, there has been little research into the contribution of peroxides and carbonyls to limonene SOA and their behaviors in aerosol formation are only vaguely understood, to the best of our knowledge. 
The focus of this study is to investigate the oxidation regime and SOA composition in limonene ozonolysis, especially for the roles of different DBs, radicals, and water. We consider the generation of SCIs, $\mathrm{OH}$ radicals, and peroxides in discussions of the oxidation regime in the reaction system. Furthermore, peroxides and carbonyls are taken as representatives to study their behaviors in SOA formation.

\section{Experimental}

\subsection{Chemicals}

This study used the following: R-(+)-Limonene (SigmaAldrich, $\geq 99.0 \%$ ), 2-butanol (Sigma-Aldrich, 99.5\%), cyclohexane (Alfa Aesar, $\geq 99.9 \%$ ), potassium iodide (KI, Alfa Aesar, 99.9\%), hydrogen peroxide $\left(\mathrm{H}_{2} \mathrm{O}_{2}\right.$, Alfa Aesar, $35 \mathrm{wt} \%)$, orthophosphoric acid $\left(\mathrm{H}_{3} \mathrm{PO}_{4}\right.$, Fluka, $85 \%-$ $90 \%$ ), hemin (Sigma, $\geq 98.0 \%$ ), 4-hydroxyphenylacetic acid (Alfa Aesar, 99\%), formaldehyde (FA; SigmaAldrich, $37 \mathrm{wt} \%$ ), acetaldehyde (AA; Amethyst Chemicals, $40 \mathrm{wt} \%$ ), acetone (ACE; Fluka, $\geq 99.7 \%$ ), hydroxyacetone (HACE; Sigma-Aldrich, 90\%), GL (Sigma-Aldrich, $40 \mathrm{wt} \%$ ), MGL (Sigma-Aldrich, $40 \mathrm{wt} \%$ ), 2-butanone (Alfa Aesar, $\geq 99 \%$ ), acetonitrile (Alfa Aesar, $\geq 99.7 \%$ ), 2,4dinitrophenylhydrazine (DNPH, TCI, $50 \mathrm{wt} \%$ ), ammonia solution $\left(\mathrm{NH}_{3} \cdot \mathrm{H}_{2} \mathrm{O}\right.$, Beijing Tongguang Fine Chemicals Company, $25.0 \%-28.0 \%)$, ammonium chloride $\left(\mathrm{NH}_{4} \mathrm{Cl}\right.$, Beijing Tongguang Fine Chemicals Company, $\geq 99.5 \%$ ), sulfuric acid $\left(\mathrm{H}_{2} \mathrm{SO}_{4}\right.$, Xilong Chemical Company, 95.0\%-98.0\%), ultrapure water (18 M $\Omega$, Millipore), $\mathrm{N}_{2}$ ( $\geq 99.999 \%$, Beijing Haikeyuanchuang Practical Gas Company Limited, Beijing, China), $\mathrm{O}_{2}$ ( $\geq 99.999 \%$, Beijing Haikeyuanchuang Practical Gas Company Limited, Beijing, China), polytetrafluoroethylene (PTFE) filter membrane (Whatman Inc., $47 \mathrm{~mm}$ in diameter), and quartz microfiber filters (Whatman Inc.).

\subsection{Apparatus and procedures}

A flow tube reactor ( $2 \mathrm{~m}$ length, $70 \mathrm{~mm}$ inner diameter, quartz wall), equipped with a water jacket for controlling the temperature, was used to investigate the ozonolysis of limonene. All the experiments were conducted at $298 \pm 0.5 \mathrm{~K}$ in darkness. $\mathrm{O}_{3}$ was generated by $\mathrm{O}_{2}$ photolysis in a $2 \mathrm{~L}$ quartz tube with a low-pressure $\mathrm{Hg}$ lamp, and the detailed quantification method of $\mathrm{O}_{3}$ was described in our previous study (Chen et al., 2008). $\mathrm{H}_{2} \mathrm{O}_{2}$ produced by UV irradiation of $\mathrm{O}_{2}$ and trace water was measured in control experiments and deducted from the results. Limonene gas was generated by passing $\mathrm{N}_{2}$ flow over liquid limonene in a diffusion tube at the selected temperature, and $\mathrm{OH}$ scavenger (2-butanol or cyclohexane) gas was generated with a bubbler. The concentrations of limonene and the $\mathrm{OH}$ scavenger were determined using a gas chromatograph with a flame ionization detector (GC-FID, Agilent 7890A, USA). Water vapor was generated by passing $\mathrm{N}_{2}$ through a water bubbler, which contained a
Table 1. Experimental conditions.

\begin{tabular}{lrrlrr}
\hline Exp. & $\begin{array}{r}{[\text { Limonene }]} \\
(\text { ppbv })\end{array}$ & $\begin{array}{r}{\left[\mathrm{O}_{3}\right]} \\
(\text { ppbv })\end{array}$ & $\begin{array}{l}\mathrm{OH} \\
\text { scavenger }\end{array}$ & $\begin{array}{r}{[\mathrm{OH}} \\
\text { scavenger }] \\
(\text { ppmv })\end{array}$ & $\begin{array}{r}\mathrm{RH} \\
(\%)\end{array}$ \\
\hline L(No-sca) & 280 & 500 & - & - & $0-90$ \\
L(2-But) & 280 & 500 & 2-butanol & 350 & $0-90$ \\
L(C-hex) & 280 & 500 & cyclohexane & 420 & $0-90$ \\
H(No-sca) & 183 & 19000 & - & - & $0-90$ \\
H(2-But) & 183 & 19000 & 2-butanol & 350 & $0-90$ \\
H(C-hex) & 183 & 19000 & cyclohexane & 420 & $0-90$ \\
\hline
\end{tabular}

Note: $\mathrm{L}$, low $\left[\mathrm{O}_{3}\right]$ / [limonene] ratio; $\mathrm{H}$, high $\left[\mathrm{O}_{3}\right] /$ [limonene] ratio; No-sca, no scavenger; 2-But, 2-butanol; C-hex, cyclohexane; $\mathrm{RH}$, relative humidity.

carborundum disc submerged in ultrapure water $(18 \mathrm{M} \Omega)$. The mixing gas, including limonene, $\mathrm{OH}$ scavenger, ozone, and dry or wet synthetic air $\left(80 \% \mathrm{~N}_{2}\right.$ and $\left.20 \% \mathrm{O}_{2}\right)$, was successively introduced into the reactor. With a total flow rate of 2 standard $\mathrm{L} \mathrm{min}^{-1}$, the residence time was estimated to be $240 \mathrm{~s}$.

To explore the reaction mechanism of endocyclic and exocyclic DBs' ozonolysis and the effect of multi-generation oxidation in limonene ozonolysis, we conducted two sets of experiments with different ratios of ozone to limonene concentration. In the following, $\left[\mathrm{O}_{3}\right]$ denotes the concentration of ozone, [limonene] denotes the concentration of limonene, and $\left[\mathrm{O}_{3}\right] /$ [limonene] denotes the concentration ratio of ozone to limonene. In the low $\left[\mathrm{O}_{3}\right] /$ [limonene] experiments, the initial concentrations of limonene and ozone were $\sim 280$ and $\sim 500 \mathrm{ppbv}$, respectively, whereas in the high $\left[\mathrm{O}_{3}\right] /$ [limonene] experiments, the initial concentrations of limonene and ozone were $\sim 183 \mathrm{ppbv}$ and $\sim 19 \mathrm{ppmv}$, respectively. In both sets of experiments, sufficient quantities of 2-butanol and cyclohexane were added to scavenge $\mathrm{OH}$ radicals in the $\mathrm{RH}$ range of $0 \%-90 \%$. In the tables and figures, the low-ratio and high-ratio experiments are denoted by $\mathrm{L}$ and $\mathrm{H}$, respectively, and the conditions in the absence of the scavenger, in the presence of 2-butanol, and in the presence of cyclohexane are denoted by No-sca, 2-But, and C-hex, respectively. The experimental conditions are listed in Table 1.

According to previous studies, the rate constant of the endocyclic DB reaction with ozone in limonene ozonolysis is $2 \times 10^{-16} \mathrm{~cm}^{3}$ molecule ${ }^{-1} \mathrm{~s}^{-1}$ (Atkinson, 1990; Shu and Atkinson, 1994), while the exocyclic DB reaction with ozone is about 30 times slower than the endocyclic DB reaction (Zhang et al., 2006). Based on those rate constants, we estimate that at a low $\left[\mathrm{O}_{3}\right]$ / [limonene] ratio, less than $1 \%$ exocyclic DB is ozonated, so this situation mainly represents first-generation oxidation. In this circumstance, because the ozone concentration is low, the $\mathrm{OH}$ reaction would impact the amount of limonene consumed by $\mathrm{O}_{3}$. In the presence of the $\mathrm{OH}$ scavenger, $\sim 42 \%$ endocyclic $\mathrm{DB}$ reacted with $\mathrm{O}_{3}$, while in the absence of the scavenger, $\sim 38 \%$ endocyclic DB reacted with $\mathrm{O}_{3}$. At a high $\left[\mathrm{O}_{3}\right] /$ [limonene] ratio, more than $99 \%$ endocyclic DB and about $51 \%$ exocyclic DB re- 
acted with ozone, and since the ozone concentration in this situation was high, the $\mathrm{OH}$ effect on the ozonolysis was presumed to be unimportant. The latter condition, which contained multi-generation oxidation processes, was more likely to occur since the ratio of $\left[\mathrm{O}_{3}\right]$ to [limonene] was similar to the ratio in the real atmosphere.

It should be noted that one advantage of the flow tube reactor is that the wall would be in equilibrium with the gas phase after a stationary period. According to our observations, this process usually requires about $2 \mathrm{~h}$. Thus, to stabilize the system and diminish the wall effect to the greatest extent possible, we ran the reactor for $2 \mathrm{~h}$ prior to taking measurements. And after the experiments, the reactor was rinsed with ultrapure water and blown dry with $\mathrm{N}_{2}$.

\subsection{Products' analysis}

To better investigate the gas-particle partitioning of products formed in limonene ozonolysis, we analyzed the gas-phase and particle-phase products simultaneously. We measured total peroxides and a series of low-molecule-weight (LMW) peroxides. In the following discussion we regard those peroxides that could be detected by high performance liquid chromatography (HPLC) to be LMW peroxides, while we take the peroxides undetermined by HPLC to be high-moleculeweight (HMW) peroxides. For particle-phase peroxides' detection, a PTFE filter was used for the SOA collection, and the mass of SOA was measured by a semi-micro balance (Sartorius, Germany). Since the control experiment showed that a long-duration collection led to the loss of some peroxides in particles, the collection time was controlled to be $3 \mathrm{~h}$ for each filter, and the accuracy of the particulate products' analysis was discussed in the Supplement. Each loaded PTFE filter was extracted with $20 \mathrm{~mL} \mathrm{H}_{3} \mathrm{PO}_{4}$ solution (pH 3.5) using a shaker (Shanghai Zhicheng ZWY 103D, China) at $180 \mathrm{rpm}$ and $4{ }^{\circ} \mathrm{C}$ for $15 \mathrm{~min}$, and the extraction efficiency was confirmed in our previous work (Li et al., 2016). For gas-phase peroxides' detection, the air samples through the filter were collected in a glass coil collector at a temperature of $4{ }^{\circ} \mathrm{C}$ with $\mathrm{H}_{3} \mathrm{PO}_{4}$ solution ( $\mathrm{pH} 3.5$ ) serving as the rinsing solution. The coil collector is around $30 \mathrm{~cm}$ long and its effective length is about $100 \mathrm{~cm}$. The coil is similar with that used in earlier studies (Grossmann et al., 2003; Sauer et al., 1996, 1997), and the diagram of the thermostatic coil collector is provided in the Supplement.

The method for detecting the peroxides was reported in our previous studies (Hua et al., 2008; Li et al., 2016) and is only briefly described here. LMW peroxides were analyzed using HPLC (Agilent 1100, USA) coupled with postcolumn derivatization and fluorescence detection online. Peroxides separated by column chromatography reacted with $p$ hydroxyphenylacetic acid (POPHA) to form POPHA dimers under the catalysis of hemin, and then the dimers were quantified using a fluorescence detector. The standard solution of peroxides was prepared and used for calibration in each measurement. The detection limit for the gas-phase LMW peroxides was about $22 \mathrm{pptv}$, and in the particle phase the detection limit was around $0.068 \mathrm{ng} \mathrm{\mu g}^{-1}$ for $\mathrm{H}_{2} \mathrm{O}_{2}$. The accuracy of this method was estimated to be around $7 \%$, with the precision of the measurement results usually within $20 \%$. The concentration of total peroxides $\left(\mathrm{H}_{2} \mathrm{O}_{2}, \mathrm{ROOH}\right.$, and ROOR/) was determined using the iodometric spectrophotometric method, which is based on the reaction of peroxides and iodide ions (Docherty et al., 2005; Mutzel et al., 2013). Briefly, excessive KI solution was added to samples purged of $\mathrm{O}_{2}$. After remaining in darkness $12-24 \mathrm{~h}$ for the derivatization, the produced $\mathrm{I}_{3}^{-}$ions were quantified at $420 \mathrm{~nm}$ using a UV-VIS spectrophotometer (SHIMADZU UV-1800, Japan). The efficiency of the total peroxides' measurement was discussed in our previous work ( $\mathrm{Li}$ et al., 2016), and the detection limit of the total peroxides was about $0.92 \mathrm{ppbv}$ in the gas phase and $0.025 \mu \mathrm{g} \mu \mathrm{g}^{-1}$ in the particle phase. The accuracy of this method was estimated to be $10 \%$, with the precision of the measurement results usually within $20 \%$.

To measure the particle-phase carbonyls, SOA was collected onto a quartz microfiber filter for $3 \mathrm{~h}$. After collection, the filter was placed upside down in a conical flask, and then $5 \mathrm{~mL}$ acetonitrile, $1 \mathrm{~mL}$ DNPH saturated solution, and $50 \mu \mathrm{L} \mathrm{H}_{2} \mathrm{SO}_{4}$ solution $(0.25 \mathrm{M})$ were added into the flask in sequence. The flask was shaken at $180 \mathrm{rpm}$ and $4{ }^{\circ} \mathrm{C}$ for $3 \mathrm{~h}$ and kept in darkness for $12-24 \mathrm{~h}$ prior to detection. For the gas-phase carbonyls' measurement, gas through the filter was directly introduced into a Horibe tube, which was placed in a cold trap (Beijing Tiandijingyi TH-95-15-G, China) at about $-98^{\circ} \mathrm{C}$ to freeze the products in the tube. The Horibe tube was composed of an inlet tube ( $25 \mathrm{~cm}$ length, $4 \mathrm{~cm}$ O.D.), a coil (7 laps, $1 \mathrm{~cm}$ O.D.), and an outlet tube with a carborundum disc. The diagram of the Horibe tube is shown in the Supplement. After collection, $10 \mathrm{~mL}$ acetonitrile was added to rinse the inside of the Horibe tube to dissolve carbonyl compounds, and then the solution was mixed with DNPH saturated solution and $\mathrm{H}_{2} \mathrm{SO}_{4}$ solution to derivatize for 12$24 \mathrm{~h}$ in darkness. The derived samples were analyzed using HPLC with UV detection (Agilent 1100, USA). Details of this process are provided in our previous report (Wang et al., 2009). The detection limit of carbonyl compounds was about $0.3 \mathrm{ppbv}$ in the gas phase, and in the particle phase it was $0.15 \mathrm{ng} \mathrm{\mu g}^{-1}$ in terms of FA. The accuracy of this method was estimated to be $8 \%$ and the precision of the measurement results was within $30 \%$. Since the yields of both ACE and MGL were low, especially under some conditions, their uncertainty might be high and the precision was within $80 \%$.

\subsection{Wall loss experiments}

To increase the accuracy of the results, we designed and conducted a series of control experiments to quantify the wall loss effect, including gaseous products and aerosol wall loss evaluation. Gas-containing peroxide constituents were generated by passing $\mathrm{N}_{2}$ through a diffusion tube, at a controlled 
temperature of $4{ }^{\circ} \mathrm{C}$, which contained a certain peroxide solution. The synthetic method of multiple organic peroxides was described in our previous work (Huang et al., 2013). Gas-containing carbonyl constituents were prepared by injecting a liquid substance into an evacuated steel canister (15 L, Entech Instruments). Then $\mathrm{N}_{2}$ was added constantly until the pressure in the canister reached 30 psi. The outlet of the canister was linked with a mass flow controller that regulated the gas flow rate. The gas-containing peroxides or carbonyls were mixed with synthetic air at different $\mathrm{RH}$ levels and introduced into the reactor at a rate of 2 standard $\mathrm{L} \min ^{-1}$, and the concentrations of peroxides and carbonyls were controlled to be similar to the concentrations of products observed in limonene ozonolysis. After the gas mixture was introduced into the flow tube, a period of approximately $2 \mathrm{~h}$ was needed for the gas and wall to become balanced, and then the measurements began. The aerosol wall loss experiment used two-stage reaction equipment that contained two flow tube reactors. In order to explore the wall loss effect on pure SOA, the first reactor was used to generate aerosol, so that limonene and $\mathrm{O}_{3}$ had sufficient time to react completely. The gas-containing aerosol from the first reactor was mixed with synthetic air at different RH levels and introduced into the second reactor at a rate of 2 standard $\mathrm{L} \mathrm{min}^{-1}$. The particles at the inlet and outlet of the second reactor were collected on PTFE filters and measured by a balance to calculate the SOA concentration. The wall loss fraction of the gas-phase constituent or SOA was determined as the difference between the inlet and outlet concentrations divided by the inlet concentration as Eq. (S1) in the Supplement. The wall loss experiments were conducted in the $\mathrm{RH}$ range of $0 \%-90 \%$, and the profiles of loss fractions as a function of RH could be used to correct products and SOA yields to diminish the wall loss effect.

\section{Results and discussion}

\subsection{Wall loss correction}

The wall loss fractions of LMW peroxides increased with increasing $\mathrm{RH}$, and this tendency was especially obvious for performic acid (PFA) and peracetic acid (PAA), whose loss fractions increased successively with $\mathrm{RH}$. For $\mathrm{H}_{2} \mathrm{O}_{2}$ and hydroxymethyl hydroperoxide (HMHP), their wall loss fractions went up quickly above $50 \% \mathrm{RH}$, yet they did not have a large change below $50 \%$ RH. Generally speaking, HMHP had the highest wall loss fraction, reaching $\sim 0.25$ at $90 \%$ $\mathrm{RH}$, while PFA had the lowest wall loss fraction. The average of these LMW peroxides loss fractions was used to correct the wall loss effect for gas-phase HMW peroxides.

As for carbonyl compounds, the variation of their wall loss fractions with RH was not very obvious. The loss curves of FA, AA, and ACE were somewhat irregular. The wall loss fractions of HACE, GL, and MGL were lowest at $10 \% \mathrm{RH}$, and then they gradually arose with increasing water vapor concentration. The higher loss fractions of GL and MGL compared with other carbonyls could be attributed to their inclination towards hydration. FA had the lowest wall loss fraction around 0.03, while MGL had the highest loss fraction around 0.12 .

The wall loss effect on SOA was also investigated from $0 \%$ to $90 \% \mathrm{RH}$. The SOA wall loss fraction was $\sim 0.06$ in dry conditions, then it increased slightly with water vapor concentration. The SOA loss fraction was $\sim 0.11$ and $\sim 0.17$ at $50 \%$ and $90 \% \mathrm{RH}$, respectively. The dependencies of the peroxides, carbonyls, and SOA wall loss fractions on $\mathrm{RH}$ are provided in the Supplement.

\subsection{SCIs generation}

The reaction between SCIs and water, which produces $\alpha$-hydroxyalkyl hydroperoxides (HAHPs) decomposing to $\mathrm{H}_{2} \mathrm{O}_{2}$, carbonyls, and carboxylic acids, is thought to be an essential source of these compounds and serves as a principle source of $\mathrm{H}_{2} \mathrm{O}_{2}$ formation without light (Becker et al., 1990, 1993; Gäb et al., 1985; Sauer et al., 1999). Figure 1 shows the dependence of $\mathrm{H}_{2} \mathrm{O}_{2}$ yield and HMHP yield on $\mathrm{RH}$, and the six profiles in each subgraph represent conditions at a low or high $\left[\mathrm{O}_{3}\right] /$ [limonene] ratio in the presence or absence of the $\mathrm{OH}$ scavenger (2-butanol or cyclohexane). The molar yield used here is defined as the ratio of the product's number of moles to the number of moles of limonene consumed, as given by Eq. (S2). It was obvious that, even in different cases, the variations of $\mathrm{H}_{2} \mathrm{O}_{2}$ yield and $\mathrm{HMHP}$ yield with $\mathrm{RH}$ had similar tendencies, both of which increased significantly from $0 \% \mathrm{RH}$ to $70 \% \mathrm{RH}$, and then they approached the limiting values. There was little effect of the $\mathrm{OH}$ scavenger. At a low $\left[\mathrm{O}_{3}\right] /$ [limonene] ratio, the maximum $\mathrm{H}_{2} \mathrm{O}_{2}$ yield was $\sim 24.00 \%$ without the $\mathrm{OH}$ scavenger, $\sim 24.60 \%$ with 2-butanol, and $\sim 22.95 \%$ with cyclohexane. At a high $\left[\mathrm{O}_{3}\right] /$ [limonene] ratio, the maximum $\mathrm{H}_{2} \mathrm{O}_{2}$ yield reached $\sim 41.20 \%$ without the $\mathrm{OH}$ scavenger, $\sim 41.80 \%$ with 2 butanol, and $\sim 40.50 \%$ with cyclohexane. As for HMHP, its yield was much higher at a high $\left[\mathrm{O}_{3}\right] /$ [limonene] ratio $(\sim 5.43 \%)$ than at a low $\left[\mathrm{O}_{3}\right] /$ [limonene] ratio $(\sim 0.62 \%)$, with the specific information found in Fig. 1. It is usually believed that $\mathrm{H}_{2} \mathrm{O}_{2}$ has two generation pathways: $\mathrm{HO}_{2}$ self-reaction and HAHPs' decomposition. The former pathway is considered as a main contributor to $\mathrm{H}_{2} \mathrm{O}_{2}$ during daytime, while the latter is regarded to occur without photochemistry. In the reaction system discussed here, when we applied a box model coupled with the limonene reaction mechanism extracted from Master Chemical Mechanism (MCM) v3.3 (http://mcm.leeds.ac.uk/MCMv3.3.1, last access: 15 March 2018) to simulate the reaction, the yield of $\mathrm{H}_{2} \mathrm{O}_{2}$ formed from the $\mathrm{HO}_{2}$ self-reaction was estimated to be less than $0.1 \%$ under both dry and wet conditions. When the 2-butanol or cyclohexane reaction mechanism was taken into consideration, the contribution of this pathway to $\mathrm{H}_{2} \mathrm{O}_{2}$ 

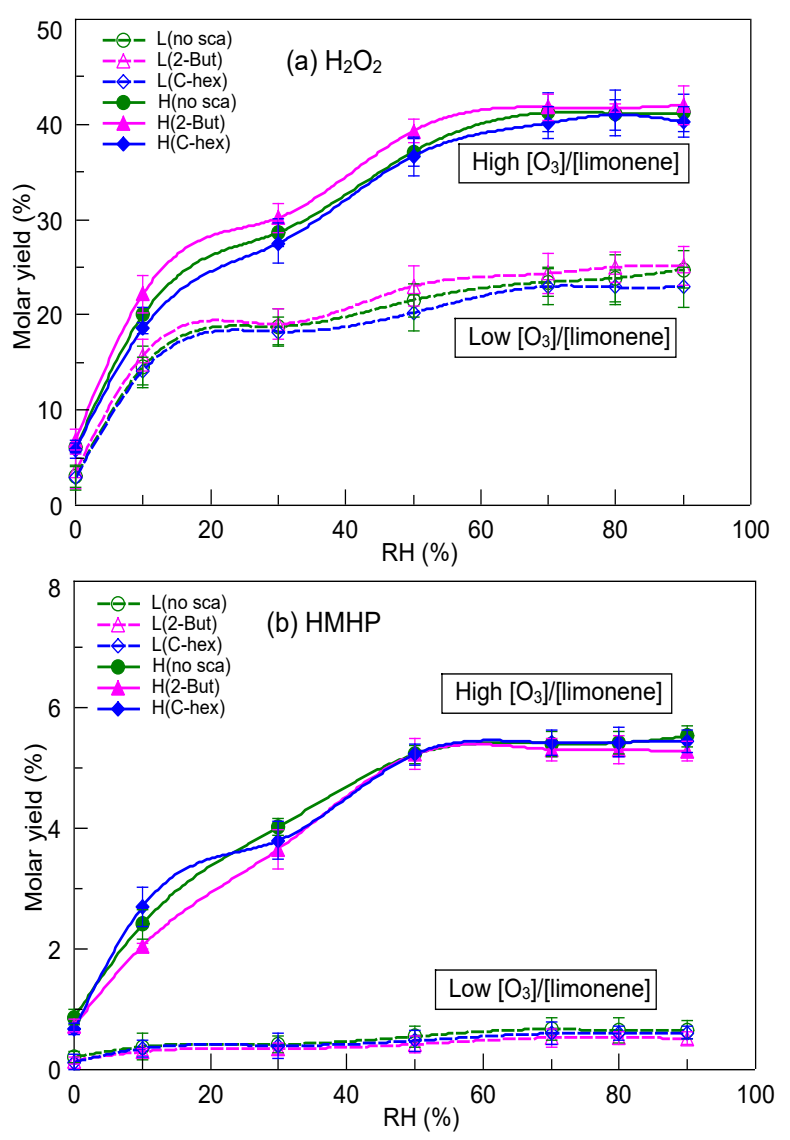

Figure 1. Dependence of (a) $\mathrm{H}_{2} \mathrm{O}_{2}$ yield and (b) HMHP yield on relative humidity $(\mathrm{RH})$ at a low or high $\left[\mathrm{O}_{3}\right] /$ [limonene] ratio in the presence or absence of the $\mathrm{OH}$ scavenger (2-butanol or cyclohexane). $\mathrm{H}_{2} \mathrm{O}_{2}$, hydrogen peroxide; HMHP, hydroxymethyl hydroperoxide; $\mathrm{L}$, low $\left[\mathrm{O}_{3}\right]$ / [limonene] ratio; $\mathrm{H}$, high $\left[\mathrm{O}_{3}\right]$ / [limonene] ratio; No-sca, no scavenger; 2-But, 2-butanol; C-hex, cyclohexane.

formation was still very limited; hence, it was assumed that the $\mathrm{HO}_{2}$ self-reaction was not important for $\mathrm{H}_{2} \mathrm{O}_{2}$ generation in this reaction system. Under dry conditions, a small amount of water vapor might desorb from the flow tube wall and participate in reactions, resulting in a small amount of $\mathrm{H}_{2} \mathrm{O}_{2}$ formation. Thus, the high $\mathrm{H}_{2} \mathrm{O}_{2}$ yield observed here might be mainly attributed to SCIs' reaction with water.

From $0 \%$ to $70 \% \mathrm{RH}$, both the $\mathrm{H}_{2} \mathrm{O}_{2}$ yield and HMHP yield were promoted significantly by increasing $\mathrm{RH}$, indicating that the reaction with water gradually became dominant for limonene SCIs. Jiang et al. (2013) suggested that the formation of HAHPs was the most favorable pathway for limonene SCIs' reaction with $\mathrm{H}_{2} \mathrm{O}$, and the subsequent decomposition of HAHPs was thought to be prior to generation of aldehyde and $\mathrm{H}_{2} \mathrm{O}_{2}$ (Chen, 2016; Kumar, 2014). Although theoretical calculation results indicate that HAHPs' decomposition is slow, some studies proved that water and acid molecules could greatly promote the decomposition process (Anglada et al., 2002, 2011; Aplincourt and Anglada, 2003;
Crehuet et al., 2001), and $\mathrm{H}_{2} \mathrm{O}_{2}$ formation from HAHPs' decomposition occurs very rapidly (Chen et al., 2016; Winterhalter et al., 2000). The fact that few HAHPs larger than HMHP were identified in alkene ozonolysis also provided evidence for the rapid decomposition of large HAHPs. Above $70 \% \mathrm{RH}$, the appearance of the limiting values of $\mathrm{H}_{2} \mathrm{O}_{2}$ yield and HMHP yield suggested that the water vapor concentration was high enough that the bimolecular reaction of SCIs and $\mathrm{H}_{2} \mathrm{O}$ suppressed the unimolecular decomposition of SCIs and the reactions of SCIs with other products. In previous studies, the unimolecular decomposition of SCIs and the reactions of SCIs with water showed strong structure dependence. For $\mathrm{CH}_{2} \mathrm{OO}$ and anti- $\mathrm{CH}_{3} \mathrm{CHOO}$, the atmospheric lifetimes of their bimolecular reactions with $\mathrm{H}_{2} \mathrm{O}$ and $\left(\mathrm{H}_{2} \mathrm{O}\right)_{2}$ were less than $1 \mathrm{~ms}$, while their lifetimes of unimolecular reaction were much longer (Lin et al., 2016; Sheps et al., 2014; Taatjes et al., 2013; Welz et al., 2012). For syn$\mathrm{CH}_{3} \mathrm{CHOO}$ and $\left(\mathrm{CH}_{3}\right)_{2} \mathrm{COO}$, the atmospheric lifetimes of their bimolecular reactions with $\mathrm{H}_{2} \mathrm{O}$ and $\left(\mathrm{H}_{2} \mathrm{O}\right)_{2}$ were more than $100 \mathrm{~ms}$, while their lifetimes of unimolecular reaction were just a few milliseconds at $298 \mathrm{~K}$ (Drozd et al., 2017; Huang et al., 2015; Long et al., 2018; Sheps et al., 2014; Taatjes et al., 2013; Welz et al., 2014). For larger SCIs their atmospheric lifetimes of unimolecular reaction and bimolecular reactions with $\mathrm{H}_{2} \mathrm{O}$ and $\left(\mathrm{H}_{2} \mathrm{O}\right)_{2}$ were not quantified. Tillmann et al. (2010) inferred that about $46 \%$ of ECIs formed from $\alpha$-pinene ozonolysis would stabilize and at $44 \% \mathrm{RH}$ about $65 \%$ of SCIs formed $\mathrm{H}_{2} \mathrm{O}_{2}$ after reacting with water and $28 \%$ of SCIs decomposed. Yao et al. (2014) showed that a large fraction of ECIs formed from $\alpha$-cedrene were stabilized and the unimolecular decomposition of SCIs was suppressed by their bimolecular reactions. Although we could not estimate the rates of SCIs' decomposition and their reaction with water, the results here prove that the reaction with water was an essential route for limonene SCIs, and the rapid decomposition of HAHPs made an important contribution to $\mathrm{H}_{2} \mathrm{O}_{2}$ formation.

According to the experimental conditions elaborated in Sect. 2.2, we tried to calculate the contribution of endocyclic DB and exocyclic DB ozonolysis to $\mathrm{H}_{2} \mathrm{O}_{2}$ and HMHP formation, and furthermore, infer the SCIs generated in the ozonolysis of different DBs. The predicted SCI yield was derived by combining the limiting yields of $\mathrm{H}_{2} \mathrm{O}_{2}$ and HMHP together, as in Eq. (S3), based on the assumption that the limiting yield of $\mathrm{H}_{2} \mathrm{O}_{2}$ was equal to the large SCI yield (Hasson, 2001a, b). Considering that a portion of SCIs might undergo unimolecular decomposition, a lower limit yield of SCIs formed in limonene ozonolysis was estimated here. Additionally, as described in Sect. 3.3, the results demonstrated that the $\mathrm{OH}$ yield was not obviously affected by $\mathrm{RH}$, and we speculated that the fraction of SCIs that decomposed and formed $\mathrm{OH}$ radicals was small. It was observed that the $\mathrm{OH}$ scavenger did not have a large impact on the SCIs' measurement results, while a big difference existed between the ozonolysis of two DBs. The SCI yield of the endocyclic DB ozonol- 


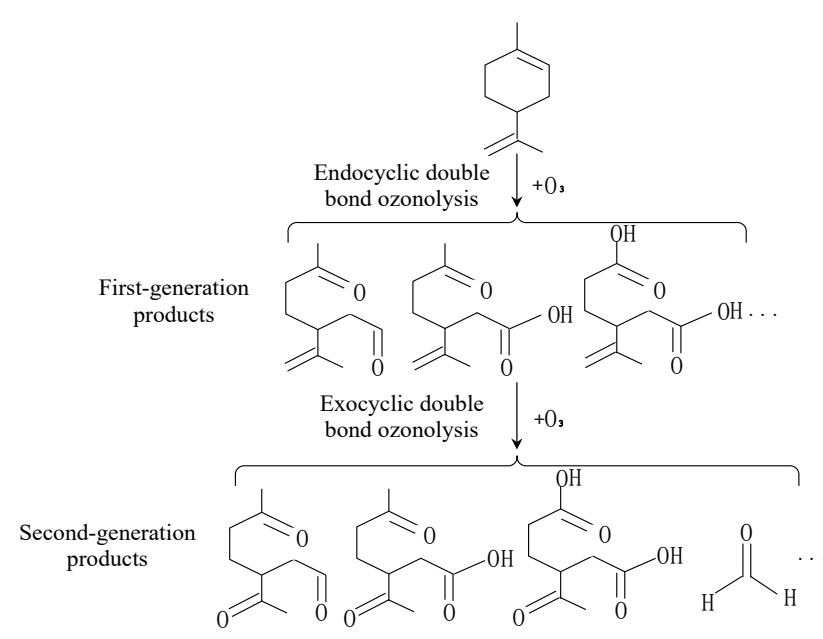

Figure 2. The reaction scheme of endocyclic and exocyclic double bonds in limonene ozonolysis.

ysis was around $24.45 \%$, yet the exocyclic DB ozonolysis had a larger stabilization fraction of ECIs, which was about $42.90 \%$. It should be noted that, since our experiments just isolated the ozonolysis of different DBs according to their discrepancy in reaction rates, the SCI yield of the exocyclic DB ozonolysis estimated here was not for a specific product formed from endocyclic DB ozonolysis but was the sum of first-generation products with a remaining double bond, as shown in Fig. 2. The results meant that, even though exocyclic DB ozonolysis is much slower than endocyclic DB, it plays a non-negligible role in generating SCIs in limonene ozonolysis.

\subsection{OH radicals generation}

In this study, $\mathrm{OH}$ yield was determined by adding sufficient 2-butanol as a scavenger and measuring how much 2butanone was generated. Aschmann et al. (2002) suggested that using 2-butanol to measure $\mathrm{OH}$ formation would be more accurate than using cyclohexane. The yield of 2-butanone formed from the reaction of 2-butanol and $\mathrm{OH}$ was detected previously (Aschmann et al., 2002; Baxley and Wells, 1998; Chew and Atkinson, 1996), and we used 0.66, which is the average of the reported values (Forester and Wells, 2011), to calculate $\mathrm{OH}$ radicals' yield. The results showed that the yield of $\mathrm{OH}$ radicals produced from endocyclic $\mathrm{DB}$ ozonolysis was $0.65 \pm 0.21$, while for exocyclic $\mathrm{DB}$, the $\mathrm{OH}$ yield was $0.24 \pm 0.13$. The $\mathrm{OH}$ generation did not show a clear dependence on water vapor concentration. The $\mathrm{OH}$ yield of endocyclic DB ozonolysis was within the range of published values, while the $\mathrm{OH}$ yield of exocyclic $\mathrm{DB}$ ozonolysis was determined to be higher than that reported by Herrmann et al. (2010). The effect of water on $\mathrm{OH}$ formation in alkene ozonolysis is still under debate as there are discrepancies among the existing publications. Anglada et al. (2002) used quantum mechanical calculations to indicate that water could increase $\mathrm{OH}$ production, and Tillmann et al. (2010) reported higher $\mathrm{OH}$ yield under humid conditions. Nevertheless, more studies showed that $\mathrm{OH}$ formation was independent of water vapor concentration (Aschmann et al., 2002; Atkinson and Aschmann, 1993; Atkinson et al., 1992; Berndt et al., 2003; Forester and Wells, 2011; Hasson et al., 2003). The fact that the $\mathrm{OH}$ yields of both unsaturated bonds were not obviously affected by RH suggests that the major pathway of $\mathrm{OH}$ generation in limonene ozonolysis is the decomposition of ECIs through hydroperoxide channel. The possibility that other $\mathrm{OH}$ formation pathways also exist cannot be totally excluded, but we speculate that any other pathways are not significant. Hence, it could be concluded that in limonene ozonolysis, the endocyclic DB is inclined to generate $\mathrm{OH}$ radicals through ECIs' decomposition, while the exocyclic DB has a higher fraction of stabilization-forming SCIs.

\subsection{Peroxycarboxylic acids generation}

In our experiments, two kinds of peroxycarboxylic acids, PFA $(\mathrm{CH}(\mathrm{O}) \mathrm{OOH})$ and PAA $\left(\mathrm{CH}_{3} \mathrm{C}(\mathrm{O}) \mathrm{OOH}\right)$, were observed, and the yields of PFA and PAA both showed large discrepancies between the low-ratio and high-ratio experiments (Fig. 3). The yields of PFA and PAA at a high $\left[\mathrm{O}_{3}\right] /$ [limonene] ratio were about 3 times as much as those at a low $\left[\mathrm{O}_{3}\right] /$ [limonene] ratio. When the exocyclic DB was ozonated, the generation of PFA and PAA was enhanced to a large extent compared with only endocyclic DB ozonolysis, indicating that exocyclic DB ozonolysis had an important impact on PFA and PAA. As far as we know, this was the first time that such high yields of PFA and PAA in alkene ozonolysis have been reported. For both PFA and PAA, the highest molar yields were observed when no $\mathrm{OH}$ scavenger was used, demonstrating that the $\mathrm{OH}$ reaction contributed to part of their formation. When $\mathrm{OH}$ radicals were scavenged, we speculated that PFA and PAA were mainly formed through ECIs' isomerization and decomposition following the generation of $\mathrm{HC}(\mathrm{O}) \mathrm{OO}$ and $\mathrm{CH}_{3} \mathrm{C}(\mathrm{O}) \mathrm{OO}$ radicals. These radicals could further react with $\mathrm{HO}_{2}$ and form peroxycarboxylic acids, which provided a plausible explanation for the higher yields of PFA and PAA observed in experiments with 2butanol instead of cyclohexane.

The yields of PFA and PAA had a positive relationship with water vapor concentration in all the cases, reaching the highest level at $90 \%$ RH. Model simulation results significantly underestimated the PAA formation and ignored the $\mathrm{RH}$ effect, indicating some missing pathways of PAA generation related to water. Because of the deficiency of PFA mechanism in MCM, we did not simulate the PFA formation. However, the similar variation tendency of PFA and PAA yields could provide some evidence for the assumption that they might have similar formation mechanisms. In previous studies, the dominant formation pathway of PAA was considered to be the reaction of $\mathrm{CH}_{3} \mathrm{C}(\mathrm{O}) \mathrm{OO}$ radicals 

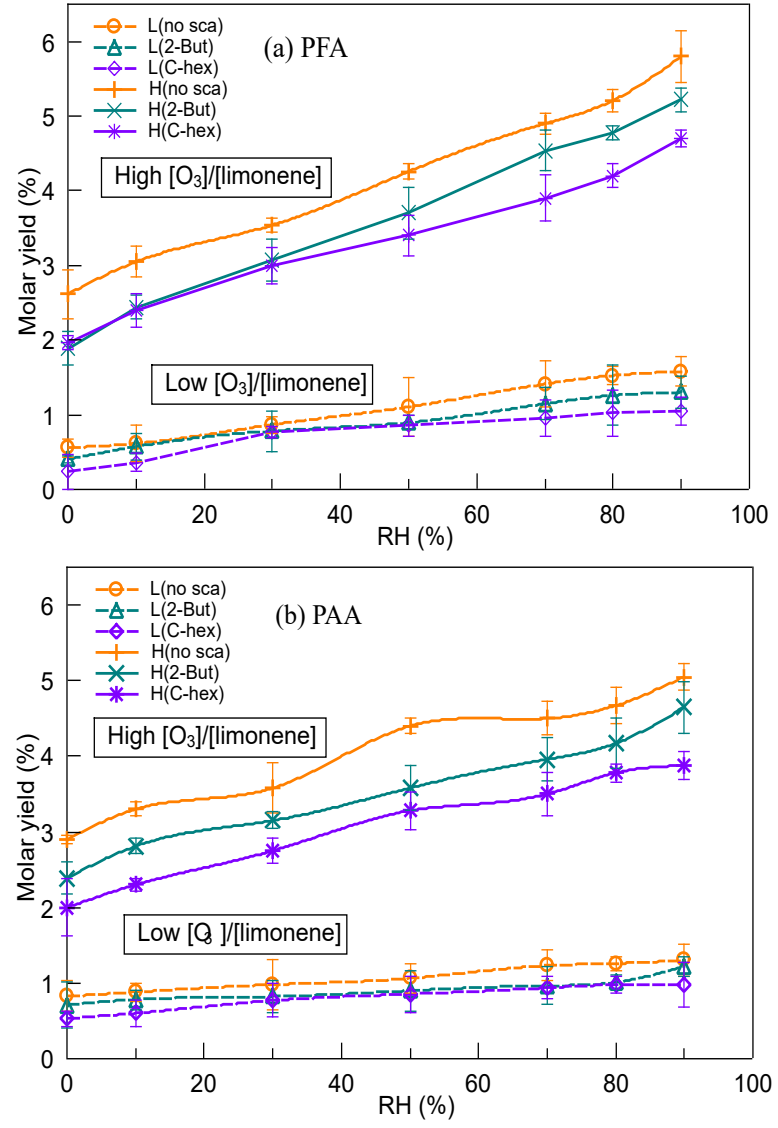

Figure 3. Dependence of (a) PFA yield and (b) PAA yield on relative humidity $(\mathrm{RH})$ at a low or high $\left[\mathrm{O}_{3}\right] /$ [limonene] ratio in the presence or absence of the $\mathrm{OH}$ scavenger (2-butanol or cyclohexane). PFA, performic acid; PAA, peracetic acid; L, low $\left[\mathrm{O}_{3}\right]$ / [limonene] ratio; $\mathrm{H}$, high $\left[\mathrm{O}_{3}\right] /$ [limonene] ratio; No-sca, no scavenger; 2-But, 2-butanol; C-hex, cyclohexane.

with $\mathrm{HO}_{2}$ radicals (Groß et al., 2014; Lightfoot et al., 1992; Winiberg et al., 2016), while the formation pathway of PFA had not been identified yet and was speculated to be the reaction of $\mathrm{HC}(\mathrm{O}) \mathrm{OO}$ radicals with $\mathrm{HO}_{2}$ radicals (Liang et al., 2015). The rate constant of the $\mathrm{RO}_{2}$ reaction with $\mathrm{HO}_{2}$ was investigated in a series of studies and was thought to be unaffected by water (Atkinson et al., 1999; Lightfoot et al., 1992; Tyndall et al., 2001; Wallington et al., 1992). Therefore, the increase of PFA and PAA yields with RH might be attributed to the promoting effect of water on $\mathrm{HC}(\mathrm{O}) \mathrm{OO}$ and $\mathrm{CH}_{3} \mathrm{C}(\mathrm{O}) \mathrm{OO}$ radical generation. Because the highly reactive peroxides were easy to lose on the wall, it might be hard for chamber studies, which usually last for hours, to observe these peroxycarboxylic acids. In field observations, PAA is widely reported in remote and urban areas (Lee et al., 2000; Liang et al., 2013; Zhang et al., 2010), yet there are few reports on PFA existence in the atmosphere (Liang et al., 2015). The results here demonstrate that limonene ozonolysis could contribute to PFA and PAA formation, and although its high instability and reactivity make PFA difficult to observe, it may have a short duration in the atmosphere.

\subsection{Particulate peroxides and $\mathrm{H}_{2} \mathrm{O}_{2}$ generation}

\subsection{1 $\mathrm{H}_{2} \mathrm{O}_{2}$ evolution at a low $\left[\mathrm{O}_{3}\right] /$ [limonene] ratio}

$\mathrm{H}_{2} \mathrm{O}_{2}$ generation from $\mathrm{SOA}$ in the aqueous phase is thought to be a possible way of producing $\mathrm{H}_{2} \mathrm{O}_{2}$ in cloud water or releasing $\mathrm{H}_{2} \mathrm{O}_{2}$ continuously after inhalation. Here, we quantitatively measured $\mathrm{H}_{2} \mathrm{O}_{2}$ generation from SOA produced in limonene ozonolysis in different cases. Considering that some unstable constituents would decay rapidly when SOA extract solution was kept at room temperature $(298 \mathrm{~K})$, we chose to keep the SOA solution at $4{ }^{\circ} \mathrm{C}$ to maintain the stability of the samples and prolong their storage time. In the low-ratio experiments, the concentration of total peroxides in solution was nearly stable in $48 \mathrm{~h}$. The $\mathrm{H}_{2} \mathrm{O}_{2}$ concentration went through a brief period of increase and then became stable. After the aqueous $\mathrm{H}_{2} \mathrm{O}_{2}$ concentration reached a plateau, the amount of particulate $\mathrm{H}_{2} \mathrm{O}_{2}$ per particle mass formed in different cases, from $0 \%$ to $90 \% \mathrm{RH}$, was calculated and shown in Table 2. Regardless of whether the $\mathrm{OH}$ scavenger was used or not, SOA produced at higher RH was inclined to have a higher capacity of producing $\mathrm{H}_{2} \mathrm{O}_{2}$. When no $\mathrm{OH}$ scavenger was used, the lowest $\mathrm{H}_{2} \mathrm{O}_{2}$ content per particle mass was $\sim 1.13 \mathrm{ng} \mathrm{\mu g}^{-1}$ in dry conditions, and the highest value was $\sim 2.45 \mathrm{ng} \mathrm{\mu g}^{-1}$ at $90 \% \mathrm{RH}$. When 2butanol was used the changing trend of $\mathrm{H}_{2} \mathrm{O}_{2}$ generation resembled the condition without the scavenger, and the minimum was $\sim 1.33 \mathrm{ng} \mathrm{\mu g}^{-1}$ at $0 \% \mathrm{RH}$, while the maximum was $\sim 2.89 \mathrm{ng} \mathrm{hg}^{-1}$ at $80 \% \mathrm{RH}$, which was a little higher than the value at $90 \% \mathrm{RH}$. It was interesting to note that, in the presence of cyclohexane, the trend of $\mathrm{H}_{2} \mathrm{O}_{2}$ generation in SOA solution differed greatly from both of the above. Even under dry conditions, the $\mathrm{H}_{2} \mathrm{O}_{2}$ content per particle mass could reach $\sim 3.22 \mathrm{ng}_{\mu \mathrm{g}}^{-1}$, and the maximum was $\sim 4.63 \mathrm{ng} \mathrm{\mu g}^{-1}$ at $90 \% \mathrm{RH}$.

\subsection{2 $\mathrm{H}_{2} \mathrm{O}_{2}$ evolution at a high $\left[\mathrm{O}_{3}\right]$ / [limonene] ratio}

In the experiments with a high $\left[\mathrm{O}_{3}\right] /$ [limonene] ratio, SOA produced with different scavengers was found to have different rates of $\mathrm{H}_{2} \mathrm{O}_{2}$ generation in solution at $4{ }^{\circ} \mathrm{C}$, according to which we determined appropriate detection frequency and total duration for the three kinds of SOA. SOA produced without the $\mathrm{OH}$ scavenger had the lowest rate of $\mathrm{H}_{2} \mathrm{O}_{2}$ generation, so an 8-day measurement result was reported here. For SOA produced in the presence of 2-butanol, $\mathrm{H}_{2} \mathrm{O}_{2}$ generation was a little faster than the former and reached the limiting value within 6 days. However, SOA produced with cyclohexane had a much faster rate than both of the above, and the $\mathrm{H}_{2} \mathrm{O}_{2}$ concentration in solution became stable within 3 days. For these three types of SOA, the total peroxides' con- 
Table 2. $\mathrm{H}_{2} \mathrm{O}_{2}$ generation per particle mass $\left(\mathrm{ng} \mathrm{ug}^{-1}\right)$ in SOA formed with different $\mathrm{OH}$ scavengers in the relative humidity (RH) range of $0 \%-90 \%$ at a low $\left[\mathrm{O}_{3}\right] /[$ limonene] ratio.

\begin{tabular}{lrrrrrrr}
\hline & $0 \% \mathrm{RH}$ & $10 \% \mathrm{RH}$ & $30 \% \mathrm{RH}$ & $50 \% \mathrm{RH}$ & $70 \% \mathrm{RH}$ & $80 \% \mathrm{RH}$ & $90 \% \mathrm{RH}$ \\
\hline No-sca & $1.13 \pm 0.22$ & $1.42 \pm 0.40$ & $1.53 \pm 0.28$ & $1.88 \pm 0.16$ & $2.24 \pm 0.42$ & $2.26 \pm 0.44$ & $2.45 \pm 0.48$ \\
2-But & $1.33 \pm 0.15$ & $1.56 \pm 0.18$ & $1.77 \pm 0.12$ & $2.02 \pm 0.65$ & $2.55 \pm 0.43$ & $2.89 \pm 0.42$ & $2.66 \pm 0.57$ \\
C-hex & $3.22 \pm 0.52$ & $3.95 \pm 0.43$ & $4.12 \pm 0.40$ & $4.22 \pm 0.33$ & $4.63 \pm 0.24$ & $4.26 \pm 0.33$ & $4.63 \pm 0.96$ \\
\hline
\end{tabular}

No-sca, no scavenger; 2-But, 2-butanol; C-hex, cyclohexane

centration decreased slightly in the analysis duration, which is clarified in the Supplement.

It is obvious that SOA produced in the high-ratio experiments has a greater ability of generating $\mathrm{H}_{2} \mathrm{O}_{2}$, and Fig. 4 shows the time profiles of $\mathrm{H}_{2} \mathrm{O}_{2}$ evolution of different kinds of SOA. When no $\mathrm{OH}$ scavenger was used, $\mathrm{H}_{2} \mathrm{O}_{2}$ concentration in solution rose constantly for 6 days then became stable. The limiting value of the $\mathrm{H}_{2} \mathrm{O}_{2}$ generation was influenced by $\mathrm{RH}$, which was $\sim 5.28 \mathrm{ng}^{\mathrm{g}} \mathrm{g}^{-1}$ at $0 \% \mathrm{RH}$, then increased gradually with increasing $\mathrm{RH}$ until $80 \% \mathrm{RH}(\sim$ $14.45 \mathrm{ng} \mathrm{\mu g}^{-1}$ ). In the experiments with 2-butanol, the $\mathrm{H}_{2} \mathrm{O}_{2}$ concentration kept rising in the first 4 days, then it became stable. Under dry conditions, the limiting value of the $\mathrm{H}_{2} \mathrm{O}_{2}$ content was $\sim 7.60 \mathrm{ng} \mathrm{\mu g}^{-1}$, then it increased until $50 \% \mathrm{RH}$. SOA produced above $50 \%$ RH did not show any obvious difference, and the highest $\mathrm{H}_{2} \mathrm{O}_{2}$ content was $\sim 15.50 \mathrm{ng} \mathrm{\mu g}^{-1}$. When cyclohexane was added, the $\mathrm{H}_{2} \mathrm{O}_{2}$ concentration in solution increased rapidly on the first day then tended to become stable. The limiting value of $\mathrm{H}_{2} \mathrm{O}_{2}$ generation was also affected by water vapor concentration, yet the promoting effect was not very significant, and no large difference was observed above $30 \% \mathrm{RH}$. The limiting $\mathrm{H}_{2} \mathrm{O}_{2}$ content per particle mass was $\sim 16.64 \mathrm{ng} \mathrm{\mu g}^{-1}$ in dry conditions and was $\sim 30.00{\mathrm{ng} \mu \mathrm{g}^{-1}}^{-1}$ above $30 \% \mathrm{RH}$.

\subsubsection{Different stabilities of particulate peroxides}

According to the measurement results of the total peroxides and $\mathrm{H}_{2} \mathrm{O}_{2}$ in the SOA solution, the particulate peroxides could be roughly divided into two categories: one is unstable and could decompose or hydrate to generate $\mathrm{H}_{2} \mathrm{O}_{2}$, the other one is stable and could nearly remain unchanged in several days. Supposing that all the peroxides contained one peroxy bond, the molar fractions of stable or unstable peroxides could be calculated as follows:

$\varphi_{i}=\frac{N_{i}}{N_{\text {total }}}$

where $\varphi_{i}$ is the molar fraction of stable or unstable peroxides in particles, $N_{i}(\mathrm{~mol})$ is the number of moles of stable or unstable peroxides in particles, and $N_{\text {total }}(\mathrm{mol})$ is the number of moles of total peroxides in particles. At a low $\left[\mathrm{O}_{3}\right] /$ [limonene] ratio, the molar fraction of unstable peroxides in SOA was around $0.11-0.13$ in the case of adding no scavenger, which was similar to the case of adding 2butanol. In the presence of cyclohexane, the molar fraction of unstable peroxides would increase to $0.20-0.32$. At a high $\left[\mathrm{O}_{3}\right]$ / [limonene] ratio, the molar fractions of unstable peroxides in the case of adding no scavenger and adding 2butanol were also similar, with both of them in the range $0.13-0.25$, yet this value would reach $\sim 0.50$ when cyclohexane was used. Detailed information is provided in the Supplement. Model results showed that most peroxides produced in the reaction were $\mathrm{ROOH}$ and $\mathrm{R}(\mathrm{O}) \mathrm{OOH}$; in addition, some studies proposed that peroxyhemiacetals also made an important contribution to aerosol (Tobias and Ziemann, 2000; Tobias et al., 2000). The acetal reaction producing peroxyhemiacetals is reversible, so part of the peroxyhemiacetals in SOA may have hydrolyzed to form some peroxides. To investigate the stabilities of $\mathrm{ROOH}$ and $\mathrm{R}(\mathrm{O}) \mathrm{OOH}$, we synthesized methyl hydroperoxide (MHP) and ethyl hydroperoxide (EHP) to represent ROOH. PFA and PAA were used to represent $\mathrm{R}(\mathrm{O}) \mathrm{OOH}$. All the synthesis solutions were stored at $4{ }^{\circ} \mathrm{C}$, which was the same as the experimental condition. PFA and PAA were found to decompose and generate $\mathrm{H}_{2} \mathrm{O}_{2}$ within several days, yet MHP and EHP maintained stable. Hence, we speculate that peroxycarboxylic acids and peroxyhemiacetals might be the main components of unstable peroxides in particles, and they contribute to $\mathrm{H}_{2} \mathrm{O}_{2}$ generation in the aqueous phase.

The amount of $\mathrm{H}_{2} \mathrm{O}_{2}$ generation at a low $\left[\mathrm{O}_{3}\right]$ / [limonene] ratio measured here was comparable with the published value of $\mathrm{H}_{2} \mathrm{O}_{2}$ produced from $\alpha$-pinene $\mathrm{SOA}$ in solution (Li et al., 2016; Wang et al., 2011). However, at a high $\left[\mathrm{O}_{3}\right]$ / [limonene] ratio, the $\mathrm{H}_{2} \mathrm{O}_{2}$ generation level increased significantly, which proved that the multi-generation oxidation improved the formation of peroxycarboxylic acids and peroxyhemiacetals in particles. These results demonstrated that SOA produced in limonene ozonolysis could behave as an important source of $\mathrm{H}_{2} \mathrm{O}_{2}$ in the aqueous phase, and they also showed the difference between the SOA formed from single-unsaturated monoterpene ozonolysis and double-unsaturated monoterpene ozonolysis.

\subsubsection{The effect of the $\mathrm{OH}$ scavenger}

Prior research has provided evidence for $\mathrm{OH}$ radicals' formation in ozonolysis experiments, and the $\mathrm{OH}$ scavenger is of- 

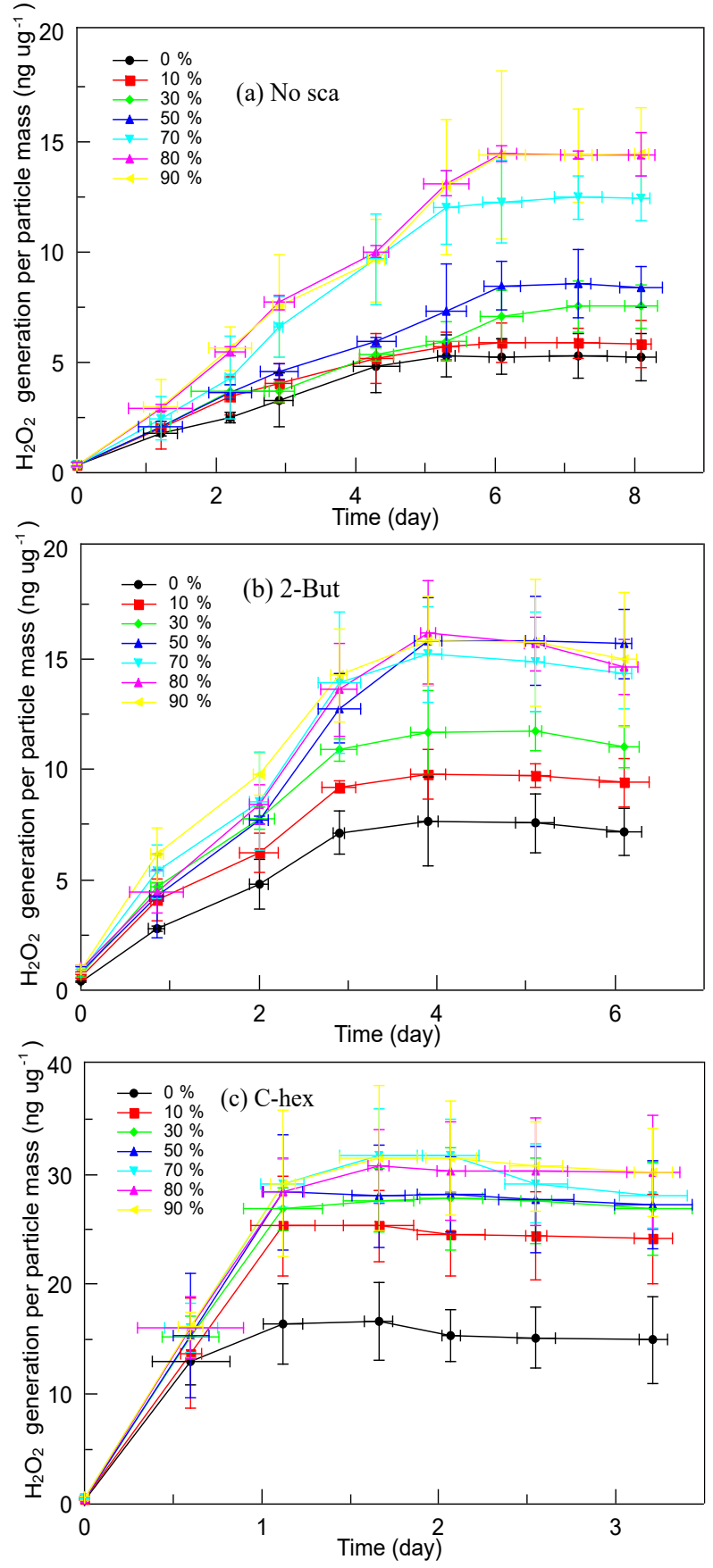

Figure 4. Time profiles of $\mathrm{H}_{2} \mathrm{O}_{2}$ evolution per particle mass of different SOA formed (a) without the $\mathrm{OH}$ scavenger, (b) with 2butanol, and (c) with cyclohexane in the relative humidity $(\mathrm{RH})$ range of $0 \%-90 \%$ at a high $\left[\mathrm{O}_{3}\right] /$ [limonene] ratio. $\mathrm{H}_{2} \mathrm{O}_{2}$, hydrogen peroxide; No-sca, no scavenger; 2-But, 2-butanol; C-hex, cyclohexane.

ten used to avoid the disturbance of the $\mathrm{OH}$ reaction. Both 2butanol and cyclohexane are commonly used $\mathrm{OH}$ scavengers, and Chew and Atkinson (1996) showed that there was no dif- ference in their abilities to scavenge $\mathrm{OH}$ radicals. However, it should be noted that the $\mathrm{OH}$ scavenger could convert $\mathrm{OH}$ radicals into a mixture of hydroperoxy $\left(\mathrm{HO}_{2}\right)$ and alkylperoxy $\left(\mathrm{RO}_{2}\right)$ radicals, and a higher $\left[\mathrm{HO}_{2}\right] /\left[\mathrm{RO}_{2}\right]$ ratio is observed when 2-butanol is used (Docherty and Ziemann, 2003; Jonsson et al., 2008a). As shown in the Sect. 3.6.1, the fact that both at a low and high $\left[\mathrm{O}_{3}\right] /$ [limonene] ratio, the SOA yield was higher with 2-butanol than cyclohexane suggested that the increase in $\mathrm{HO}_{2}$ concentration promoted SOA formation. This result is consistent with that suggested by Keywood et al. (2004) who observed the higher $\left[\mathrm{HO}_{2}\right] /\left[\mathrm{RO}_{2}\right]$ ratio, resulting in a higher SOA yield in cyclohexene ozonolysis, while Docherty and Ziemann (2003) showed that an increased $\left[\mathrm{HO}_{2}\right] /\left[\mathrm{RO}_{2}\right]$ ratio inhibited aerosol formation in $\beta$ pinene ozonolysis.

Some studies demonstrated that acid and peroxide products were sensitive to OH scavengers (Ahmad et al., 2017; Henry and Donahue, 2011; Ma et al., 2008). Here, through investigating the stabilities of particulate peroxides formed in different conditions, we showed that the choice of the $\mathrm{OH}$ scavenger would influence the types of particulate peroxides produced in the reaction. In Sect. 3.5.3, we suggest that peroxycarboxylic acids and peroxyhemiacetals be the main components of unstable peroxides in particles. The peroxyhemiacetals formed by heterogeneous reactions of peroxides and aldehydes could dissociate into these species, yet the formation of peroxyhemiacetals was not considered to be affected by the $\mathrm{OH}$ scavenger since both the peroxides and carbonyl compounds observed in the gas phase did not show large differences when the $\mathrm{OH}$ scavenger changed. We speculate that the impact of the $\mathrm{OH}$ scavenger on particulate peroxides could be mainly attributed to the formation of peroxycarboxylic acids under a different $\left[\mathrm{HO}_{2}\right] /\left[\mathrm{RO}_{2}\right]$ ratio. Keywood et al. (2004) indicated that the $\mathrm{OH}$ scavenger impacted the $\mathrm{HO}_{2}$ reaction with acyl peroxy radicals forming acid and peracid products, which were considered to have low volatility. With higher $\mathrm{HO}_{2}$ concentration, the SOA yield in the presence of 2-butanol was higher than that in the presence of cyclohexane, since the $\mathrm{HO}_{2}$-acyl peroxy reactions contributed to some low-volatility products. However, the $\mathrm{RO}_{2}$ radicals formed from cyclohexane may also participate in reactions and help produce more unstable peroxycarboxylic acids which could partition into the particle phase.

\subsection{Contribution of peroxides to SOA}

\subsubsection{SOA formation}

The yield of SOA produced from limonene ozonolysis in different cases ranging from $0 \%$ to $90 \% \mathrm{RH}$ was measured. The SOA yield is defined as the ratio of aerosol mass concentration to the mass concentration of limonene consumed, as given by Eq. (S4). In the six different cases, SOA yield was determined to be unaffected by water, yet it showed strong dependence on the reactants' ratio and the use of the $\mathrm{OH}$ 
Table 3. The SOA yield and mass fraction of particulate peroxides at a low or high $\left[\mathrm{O}_{3}\right] /$ [limonene] ratio in the presence or absence of the $\mathrm{OH}$ scavenger from $0 \%$ to $90 \%$ relative humidity $(\mathrm{RH})$.

\begin{tabular}{lrrrrrr}
\hline & L(No-sca) & L(2-But) & L(C-hex) & H(No-sca) & H(2-But) & H(C-hex) \\
\hline $0 \% \mathrm{RH}$ & $0.065 \pm 0.006$ & $0.101 \pm 0.009$ & $0.087 \pm 0.011$ & $0.401 \pm 0.016$ & $0.502 \pm 0.008$ & $0.477 \pm 0.010$ \\
$10 \% \mathrm{RH}$ & $0.091 \pm 0.010$ & $0.124 \pm 0.013$ & $0.113 \pm 0.009$ & $0.436 \pm 0.009$ & $0.534 \pm 0.009$ & $0.502 \pm 0.013$ \\
$30 \% \mathrm{RH}$ & $0.125 \pm 0.010$ & $0.147 \pm 0.011$ & $0.143 \pm 0.015$ & $0.458 \pm 0.020$ & $0.553 \pm 0.015$ & $0.506 \pm 0.011$ \\
$50 \% \mathrm{RH}$ & $0.149 \pm 0.007$ & $0.174 \pm 0.011$ & $0.161 \pm 0.016$ & $0.466 \pm 0.016$ & $0.571 \pm 0.009$ & $0.512 \pm 0.007$ \\
$70 \% \mathrm{RH}$ & $0.155 \pm 0.009$ & $0.178 \pm 0.009$ & $0.169 \pm 0.014$ & $0.486 \pm 0.023$ & $0.576 \pm 0.010$ & $0.503 \pm 0.011$ \\
$80 \% \mathrm{RH}$ & $0.169 \pm 0.013$ & $0.189 \pm 0.010$ & $0.189 \pm 0.012$ & $0.492 \pm 0.015$ & $0.580 \pm 0.013$ & $0.502 \pm 0.014$ \\
$90 \% \mathrm{RH}$ & $0.156 \pm 0.010$ & $0.183 \pm 0.013$ & $0.189 \pm 0.013$ & $0.492 \pm 0.017$ & $0.580 \pm 0.018$ & $0.506 \pm 0.016$ \\
\hline SOA yield & $0.379 \pm 0.039$ & $0.337 \pm 0.048$ & $0.288 \pm 0.038$ & $0.511 \pm 0.097$ & $0.479 \pm 0.044$ & $0.401 \pm 0.068$ \\
\hline
\end{tabular}

Note: $\mathrm{L}$, low $\left[\mathrm{O}_{3}\right]$ / [limonene] ratio; $\mathrm{H}$, high $\left[\mathrm{O}_{3}\right]$ / [limonene] ratio; No-sca, no scavenger; 2-But, 2-butanol; C-hex, cyclohexane.

scavenger, as shown in Table 3. Whether at a low or high $\left[\mathrm{O}_{3}\right] /$ [limonene] ratio, the case of no $\mathrm{OH}$ scavenger had the highest SOA yield, which suggested the effect of $\mathrm{OH}$ reaction on aerosol formation, and the order of SOA yield was no scavenger $>2$-butanol $>$ cyclohexane. The case with the highest $\mathrm{SOA}$ yield was at a high $\left[\mathrm{O}_{3}\right] /$ [ limonene] ratio without the $\mathrm{OH}$ scavenger $(0.511 \pm 0.097)$, while the lowest SOA yield was detected at a low $\left[\mathrm{O}_{3}\right] /$ [limonene] ratio with cyclohexane $(0.288 \pm 0.038)$.

\subsubsection{Peroxides' mass fraction}

In this study, we used the iodometric method to analyze the particle-phase total peroxides' content in limonene ozonolysis. The iodometric method is commonly regarded as a standard method for detecting total peroxides and it could almost quantify all kinds of peroxides (Bonn et al., 2004; Jenkin, 2004). The mass fraction used here is defined as the ratio of particulate peroxides' mass to SOA mass, as given in Eq. (S5). The average molecular weight of peroxides in particles is assumed to be $300 \mathrm{~g} \mathrm{~mol}^{-1}$, which is estimated to be slightly less than the molecular weight of peroxyhemiacetals, and this value has been used to calculate the mass of particulate peroxides in some studies (Docherty et al., 2005; Nguyen et al., 2010; Surratt et al., 2006). The mass fractions of peroxides in the six cases from $0 \%$ to $90 \%$ RH are summarized in Table 3. In each case, the peroxides' mass fraction in SOA increased slightly with $\mathrm{RH}$, and there was a significant difference between the low-ratio and high-ratio experiments, while there was little effect of the $\mathrm{OH}$ scavenger. The mass fraction of peroxides at a low $\left[\mathrm{O}_{3}\right]$ / [limonene] ratio was usually below 0.2 ; however, at a high $\left[\mathrm{O}_{3}\right] /$ [limonene] ratio the peroxides' mass fraction increased to 0.4-0.6. Docherty et al. (2005) reported that the peroxides' mass fraction in $\alpha$ pinene SOA was $\sim 0.47$, while for $\beta$-pinene SOA the fraction was $\sim 0.85$. Li et al. (2016) observed that peroxides could account for $\sim 0.21$ in $\alpha$-pinene SOA. We are the first to report the mass fraction of peroxides in SOA derived from limonene ozonolysis, highlighting the important role of or- ganic peroxides in SOA composition, especially when multigeneration oxidation happens.

\subsubsection{Peroxides' partitioning}

The molar yields of HMW peroxides in both the gas phase and the particle phase were determined in different cases. There was little effect of $\mathrm{RH}$ and the $\mathrm{OH}$ scavenger, while at a high $\left[\mathrm{O}_{3}\right] /$ [limonene] ratio the HMW peroxides' yield increased by $\sim 10 \%$ in contrast with the yield at a low $\left[\mathrm{O}_{3}\right] /$ [limonene] ratio. Furthermore, the gas-phase HMW peroxides and particle-phase HMW peroxides were discussed separately, which is shown in Fig. 5. For gas-phase HMW peroxides, the molar yield showed a decreasing tendency with increasing RH, which was obvious at a high $\left[\mathrm{O}_{3}\right]$ / [limonene] ratio. For particle-phase HMW peroxides, the molar yield showed a slight increasing dependence on $\mathrm{RH}$ and their yield was promoted significantly by the degree of oxidation. A possible explanation for the RH effect was that the water content in aerosol would increase when RH increased, and this promoted the uptake of some compounds into particles. However, some research proved that the effect of water on the partitioning of organic products seemed to be small, especially when no inorganic seed particles were used (Jonsson et al., 2006, 2008a, b). Thus, we propose that the promoting effect of water on particulate HMW peroxides can be mainly attributed to the effect of water participating in some gas-phase and particle-phase reactions, resulting in the formation of more low-volatility peroxides. The contribution of multi-generation oxidation products to SOA formation in limonene ozonolysis has been stated by some studies (Hoffmann et al., 1997; $\mathrm{Ng}$ et al., 2006), and the results here indicate that organic peroxides might account for a considerable proportion of these products. Multi-generation oxidation helps produce more low-volatility peroxides in the gas phase that could partition into particles, and moreover, it accelerates the occurrence of some heterogeneous reactions by providing more reactive species. 
Table 4. Yields $(\%)$ of carbonyls at a low or high $\left[\mathrm{O}_{3}\right] /$ [limonene] ratio in the presence or absence of the $\mathrm{OH}$ scavenger.

\begin{tabular}{lrrrrrr}
\hline & HACE & FA & AA & ACE & GL & MGL \\
\hline L(No-sca) & $2.04 \pm 0.48$ & $7.02 \pm 0.90-10.58 \pm 0.94$ & $1.32 \pm 0.24$ & $0.22 \pm 0.15$ & $0.89 \pm 0.25$ & $0.56 \pm 0.34$ \\
L(2-But) & $3.94 \pm 0.55$ & $4.90 \pm 0.86-7.77 \pm 0.86$ & $3.98 \pm 0.60$ & $0.35 \pm 0.18$ & $0.69 \pm 0.25$ & $0.55 \pm 0.44$ \\
L(C-hex $)$ & - & $5.21 \pm 0.66-8.25 \pm 0.55$ & - & - & $0.81 \pm 0.24$ & $0.67 \pm 0.56$ \\
H(No-sca) & $4.45 \pm 0.52$ & $13.11 \pm 0.63-27.00 \pm 1.56$ & $2.16 \pm 0.84$ & $0.79 \pm 0.22$ & $1.33 \pm 0.41$ & $1.35 \pm 0.61$ \\
H(2-But) & $10.15 \pm 2.11$ & $11.03 \pm 0.77-23.33 \pm 0.62$ & $7.86 \pm 1.32$ & $1.00 \pm 0.28$ & $1.25 \pm 0.36$ & $1.31 \pm 0.21$ \\
H(C-hex $)$ & - & $10.80 \pm 1.28-23.32 \pm 1.21$ & $1.89 \pm 1.22$ & $0.60 \pm 0.47$ & $1.25 \pm 0.51$ & $1.23 \pm 0.22$ \\
\hline
\end{tabular}

Note: -, below detection limit; L, low [ $\left.\mathrm{O}_{3}\right]$ / [limonene] ratio; $\mathrm{H}$, high $\left[\mathrm{O}_{3}\right]$ / [limonene] ratio; No-sca, no scavenger; 2-But, 2-butanol; C-hex, cyclohexane; HACE, hydroxyacetone; FA, formaldehyde; AA, acetaldehyde; ACE, acetone; GL, glyoxal; MGL, methylglyoxal.
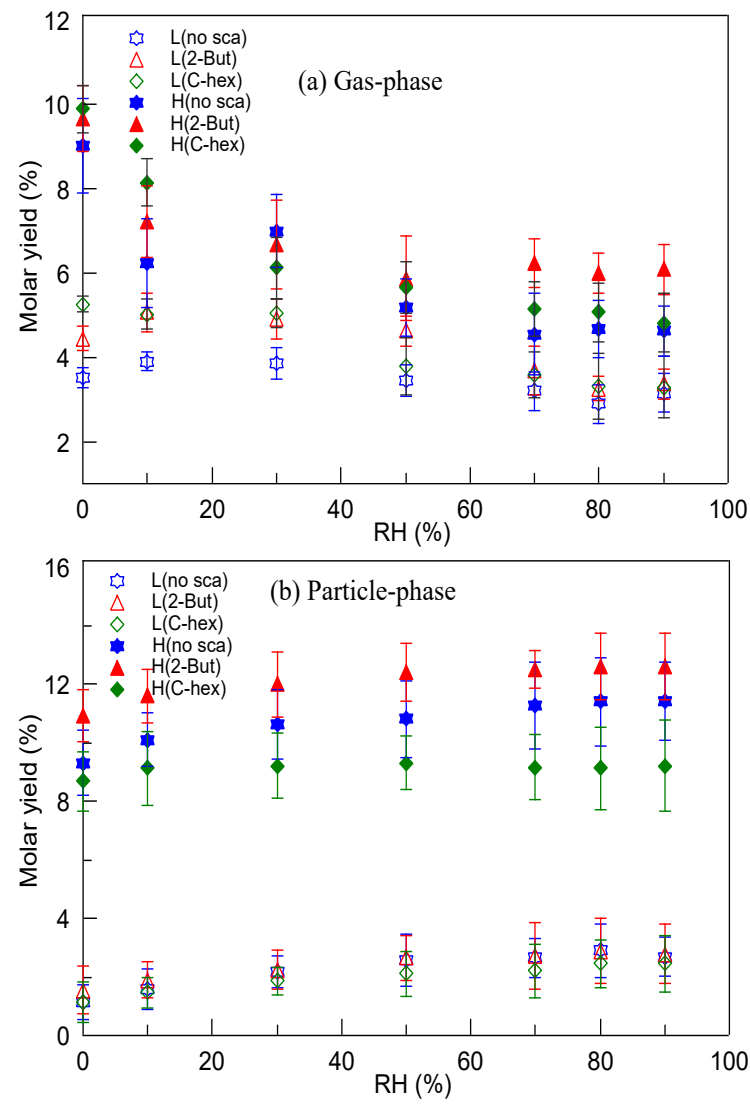

Figure 5. The variation of (a) gas-phase and (b) particle-phase high-molecular-weight peroxides' molar yields with relative humidity $(\mathrm{RH})$ at a low or high $\left[\mathrm{O}_{3}\right] /$ [limonene] ratio in the presence or absence of the $\mathrm{OH}$ scavenger (2-butanol or cyclohexane). L, low $\left[\mathrm{O}_{3}\right]$ / [limonene] ratio; $\mathrm{H}$, high $\left[\mathrm{O}_{3}\right] /$ [limonene] ratio; No-sca, no scavenger; 2-But, 2-butanol; C-hex, cyclohexane.

\subsection{Contribution of carbonyls to SOA}

\subsubsection{Carbonyls' formation}

Carbonyl compounds including HACE, FA, AA, ACE, GL, and MGL were detected in the reaction. Unlike peroxides, whose generation often showed obvious increasing depen- dence on RH, only FA yield would increase with RH and the production of other carbonyls was not significantly affected by water. The yields of HACE, AA, ACE, GL, and MGL in different cases are summarized in Table 4. The fact that HACE formed without the $\mathrm{OH}$ scavenger but did not form when cyclohexane was used indicated that HACE might be generated from $\mathrm{OH}$ reactions. As for AA and ACE, both of their yields in the presence of cyclohexane were found to be lower than the case without the scavenger, especially at a low $\left[\mathrm{O}_{3}\right]$ / [limonene] ratio. This suggested that the $\mathrm{OH}$ reaction contributed to a portion of their formation and the endocyclic DB ozonolysis did not tend to generate AA and ACE. It was speculated that these three kinds of carbonyls could also be generated from the reaction of 2-butanol or that $\mathrm{HO}_{2}$ radicals promoted their formation, so the presence of 2-butanol increased their yields. As regards to GL and MGL, RH and the $\mathrm{OH}$ scavenger did not have a large influence, and both of their yields at a high $\left[\mathrm{O}_{3}\right] /$ [limonene] ratio were higher than the conditions of a low $\left[\mathrm{O}_{3}\right] /$ [limonene] ratio. The generation of FA had a positive dependence on RH, which was illustrated in the Supplement and the total variation range could be found in Table 4 .

\subsubsection{Experimental and theoretical partitioning coefficients}

A parameter that has been used widely to describe the partitioning feature of a compound is described as follows (Pankow, 1994; Pankow and Bidleman, 1992):

$K_{\mathrm{p}, i}=\frac{F_{i} / \mathrm{TSP}}{A_{i}}$,

where $K_{\mathrm{p}, i}\left(\mathrm{~m}^{3} \mu \mathrm{g}^{-1}\right)$ is the partitioning coefficient of compound $i$, TSP $\left(\mu \mathrm{g} \mathrm{m}^{-3}\right)$ is the concentration of total suspended particulate matter, and $F_{i}\left(\mu \mathrm{g} \mathrm{m}^{-3}\right)$ and $A_{i}\left(\mu \mathrm{g} \mathrm{m}^{-3}\right)$ are the particulate and gaseous concentrations of compound $i$, respectively. The measured partitioning coefficients of FA, $\mathrm{AA}$, and $\mathrm{ACE}$ were on the magnitude of $10^{-5} \mathrm{~m}^{3} \mu \mathrm{g}^{-1}$, and the partitioning coefficients of HACE, GL, and MGL were on the magnitude of $10^{-4} \mathrm{~m}^{3} \mu \mathrm{g}^{-1}$.

Theoretical gas-particle partitioning coefficients of these compounds were calculated using the absorption equilibrium 
equation defined by Pankow (1994), which has been used widely to estimate the ability of a substance to partition into the particulate phase and to predict SOA yield in models (Griffin et al., 1999; Hohaus et al., 2015; Odum et al., 1996; Yu et al., 1999):

$$
K_{\mathrm{p}, i}=\frac{760 R T f_{\mathrm{OM}}}{\mathrm{MW}_{\mathrm{OM}} 10^{6} \zeta_{i} p_{L, i}^{0}},
$$

where $R$ is the ideal gas constant $(8.206 \times$ $10^{-5} \mathrm{~m}^{3}$ atm mol$\left.{ }^{-1} \mathrm{~K}^{-1}\right), \quad T$ is the temperature $(\mathrm{K})$, $f_{\mathrm{OM}}$ is the mass fraction of TSP that is the absorbing organic matter $(\mathrm{OM})$ and is equal to 1 here, $\mathrm{MW}$ OM $\left(\mathrm{g} \mathrm{mol}^{-1}\right)$ is the mean molecular weight of the OM phase, which is estimated to be $130 \mathrm{~g} \mathrm{~mol}^{-1}$ in this study, $\zeta_{i}$ is the activity coefficient of compound $i$ in the OM phase, which is assumed to be unity, and $p_{L, i}^{0}$ (Torr) is the vapor pressure of compound $i$, which is predicted using the method of Moller et al. (2008). The calculated gas-particle partitioning coefficients of HACE, FA, AA, ACE, GL, and MGL were $\quad 3.972 \times 10^{-8} \mathrm{~m}^{3} \mu \mathrm{g}^{-1}, \quad 2.096 \times 10^{-11} \mathrm{~m}^{3} \mu \mathrm{g}^{-1}$, $1.624 \times 10^{-10} \mathrm{~m}^{3} \mu \mathrm{g}^{-1}, \quad 6.192 \times 10^{-10} \mathrm{~m}^{3} \mu \mathrm{g}^{-1}$, $5.476 \times 10^{-10} \mathrm{~m}^{3} \mu \mathrm{g}^{-1}$, and $1.246 \times 10^{-9} \mathrm{~m}^{3} \mu \mathrm{g}^{-1}$, respectively, at $298 \mathrm{~K}$. The experimental $K_{\mathrm{p}}$ value of HACE was about 10000 times larger than the theoretical value, and for other carbonyls, the experimental $K_{\mathrm{p}}$ value was about 100000 times larger than the theoretical value. The gap between the experimental $K_{\mathrm{p}}$ and predicted $K_{\mathrm{p}}$ of GL and MGL we estimated was comparable with the results of Healy et al. (2008, 2009), but it was higher than that of Ortiz et al. (2013). The fact that the gas-particle partitioning coefficients of carbonyls observed were much higher than the theoretical values indicated that carbonyl compounds made a more important contribution to SOA formation than estimated. Although the partitioning coefficients measured in experiments showed a huge difference with the calculated values, a relationship between the measured $K_{\mathrm{p}}$ and the vapor pressure of carbonyl compounds was observed. Figure 6 shows the dependence of the measured $\lg \left(K_{\mathrm{p}}\right)$ and predicted $\lg \left(K_{\mathrm{p}}\right)$ on $\lg \left(p^{0}\right)$, and their linear fitting curves. The slope of the linear fitting equation of the predicted $\lg \left(K_{\mathrm{p}}\right)$ versus $\lg \left(p^{0}\right)$ was -0.964 , and $R^{2}$ was 0.998 . The slope of the linear fitting equation of measured $\lg \left(K_{\mathrm{p}}\right)$ versus $\lg \left(p^{0}\right)$ was -0.484 , and $R^{2}$ was 0.750 , which indicated that the $\lg \left(K_{\mathrm{p}}\right)$ of carbonyls observed in laboratory also had a negative correlation with $\lg \left(p^{0}\right)$. A plausible explanation for the large difference between the measured and predicted $K_{\mathrm{p}}$ was that carbonyl compounds were easy to polymerize and react with other species on particles, resulting in these carbonyls existing in the form of hydrates and oligomers in SOA (Corrigan et al., 2008; Hastings et al., 2005; Kroll et al., 2005; Volkamer et al., 2007). The hydrates and oligomers of carbonyls have much lower vapor pressures than their precursors, and they could reversibly return to their carbonyl monomers during analysis (Healy et al., 2008; Ortiz et al., 2013; Toda et al., 2014).

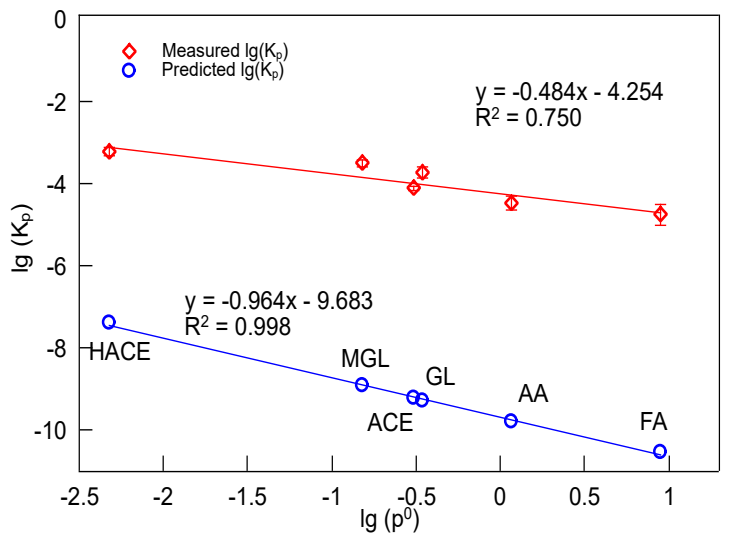

Figure 6. The relationship of measured and predicted partitioning coefficients $\left(\mathrm{m}^{3} \mu \mathrm{g}^{-1}\right)$ versus vapor pressure (atm) of carbonyls produced in limonene ozonolysis. $K_{\mathrm{p}}$, partitioning coefficients; $p^{0}$, vapor pressure, HACE, hydroxyacetone; FA, formaldehyde; AA, acetaldehyde; ACE, acetone; GL, glyoxal; MGL, methylglyoxal.

\section{Conclusions and implications}

This work reports on an experimental study of the oxidation regime and SOA composition in limonene ozonolysis with respect to the roles of different $\mathrm{DBs}$, radicals, and water. A series of oxidizing products including SCIs, $\mathrm{OH}$ radicals, and peroxides in both gaseous and particulate phases were detected. Based on the variation of $\mathrm{H}_{2} \mathrm{O}_{2}$ and HMHP generation on $\mathrm{RH}$, the importance of the reaction of limonene SCIs with water was confirmed and the yield of SCIs could be estimated to be $\sim 0.24$ for endocyclic $\mathrm{DB}$ and $\sim 0.43$ for exocyclic DB. OH yields of endocyclic and exocyclic DBs were indirectly determined to be $\sim 0.65$ and $\sim 0.24$, demonstrating the different reaction mechanisms of different DBs in limonene ozonolysis. The formation of two peroxycarboxylic acids, PFA and PAA, was observed, and their high yields were first reported in alkene ozonolysis. The yields of PFA and PAA increased with RH and the degree of oxidation, showing the effect of water and the exocyclic DB oxidation on their formation. The $\mathrm{H}_{2} \mathrm{O}_{2}$ generation from SOA in solution provided evidence for the ability of SOA to contribute oxidants in the aqueous phase. And through investigating the stabilities of particulate peroxides formed under different conditions, we showed that the choice of the $\mathrm{OH}$ scavenger would influence the types of particulate peroxides produced in the reaction. The partitioning behaviors of peroxides and carbonyls were discussed in this paper, and the results showed their importance to SOA formation. Particulate peroxides could account for less than 0.2 in limonene SOA at a low $\left[\mathrm{O}_{3}\right]$ / [limonene] ratio and 0.4-0.6 at a high $\left[\mathrm{O}_{3}\right] /[$ limonene] ratio, which proved the important role of peroxides in SOA composition, especially when multi-generation oxidation happened. Due to their ability to polymerize and react with other species on particles, the car- 
bonyl compounds often exist in SOA in the form of hydrates and oligomers, whose vapor pressures are much lower than that of their precursors. The partitioning coefficients of carbonyls observed in the laboratory were always several orders of magnitude higher than the theoretical values, indicating that their contribution to SOA was higher than estimated. Limonene is unique in many aspects because of its different DBs, suggesting that terpenes with multiple double bonds may have more complex effects on the atmosphere than previously thought. The results demonstrated the effect of the degree of oxidation, radical chemistry, and water on limonene SOA composition, while some particulate products, especially peroxides, should be studied further. Limonene chemistry in the atmosphere is characterized by the multi-generation oxidation that happens to different DBs of limonene. More laboratory evidence is needed to investigate whether the phenomena could be observed in other terpenes' oxidation that contain more than one DB.

Data availability. The data are accessible by contacting the corresponding author (zmchen@pku.edu.cn).

Supplement. The supplement related to this article is available online at: https://doi.org/10.5194/acp-18-15105-2018-supplement.

Author contributions. YG and ZC designed the study. YG conducted the experiments, analyzed data, and wrote the paper. ZC helped to interpret the results and modify the manuscript. HL contributed to some methods of analysis and helped to modify the paper.

Competing interests. The authors declare that they have no conflict of interest.

Acknowledgements. We gratefully acknowledge the National Natural Science Foundation of China (grant 21477002) and the National Key Research and Development Program of China (grant 2016YFC0202704) for financial support.

Edited by: Markus Ammann

Reviewed by: two anonymous referees

\section{References}

Ahmad, W., Coeur, C., Cuisset, A., Coddeville, P., and Tomas, A.: Effects of scavengers of Criegee intermediates and $\mathrm{OH}$ radicals on the formation of secondary organic aerosol in the ozonolysis of limonene, J. Aerosol. Sci., 110, 70-83, https://doi.org/10.1016/j.jaerosci.2017.05.010, 2017.

Andersson-Sköld, Y. and Simpson, D.: Secondary organic aerosol formation in northern Europe: A model study, J. Geophys. Res., 106, 7357-7374, https://doi.org/10.1029/2000JD900656, 2001.
Anglada, J. M., Aplincourt, P., Bofill, J. M., and Cremer, D.: Atmospheric formation of $\mathrm{OH}$ radicals and $\mathrm{H}_{2} \mathrm{O}_{2}$ from alkene ozonolysis under humid conditions, Chem. Phys. Chem., 3, 215-221, https://doi.org/10.1002/1439-7641(20020215)3:2<215::AidCphc215>3.3.Co;2-V, 2002.

Anglada, J. M., González, J., and Torrent-Sucarrat, M.: Effects of the substituents on the reactivity of carbonyl oxides. A theoretical study on the reaction of substituted carbonyl oxides with water, Phys. Chem. Chem. Phys., 13, 13034-13045, https://doi.org/10.1039/C1CP20872A, 2011.

Aplincourt, P. and Anglada, J. M.: Theoretical studies of the isoprene ozonolysis under tropospheric conditions. 2. Unimolecular and water-assisted decomposition of the $\alpha$ hydroxy hydroperoxides, J. Phys. Chem. A, 107, 5812-5820, https://doi.org/10.1021/jp034203w, 2003.

Aschmann, S. M., Arey, J., and Atkinson, R.: OH radical formation from the gas-phase reactions of $\mathrm{O}_{3}$ with a series of terpenes, Atmos. Environ., 36, 4347-4355, https://doi.org/10.1016/S13522310(02)00355-2, 2002.

Atkinson, R.: Gas-phase tropospheric chemistry of organic compounds: A review, Atmos. Environ. Part A, 24, 1-41, https://doi.org/10.1016/0960-1686(90)90438-S, 1990.

Atkinson, R. and Arey, J.: Atmospheric degradation of volatile organic compounds, Chem. Rev., 103, 4605-4638, https://doi.org/10.1021/cr0206420, 2003.

Atkinson, R. and Aschmann, S. M.: OH radical production from the gas-phase reactions of $\mathrm{O}_{3}$ with a series of alkenes under atmospheric conditions, Environ. Sci. Technol., 27, 1357-1363, 1993.

Atkinson, R., Aschmann, S. M., Arey, J., and Shorees, B.: Formation of $\mathrm{OH}$ radicals in the gas phase reactions of $\mathrm{O}_{3}$ with a series of terpenes, J. Geophys. Res., 97, 6065-6073, https://doi.org/10.1029/92JD00062, 1992.

Atkinson, R., Baulch, D. L., Cox, R. A., Hampson, R. F., Kerr, J. A., Rossi, M. J., and Troe, J.: Evaluated kinetic and photochemical data for atmospheric chemistry, organic species: Supplement VII, J. Phys. Chem. Ref. Data, 28, 191-393, https://doi.org/10.1063/1.556048, 1999.

Baxley, J. S. and Wells, J. R.: The hydroxyl radical reaction rate constant and atmospheric transformation products of 2-butanol and 2-pentanol, Int. J. Chem. Kinet., 30, 745-752, https://doi.org/10.1002/(Sici)1097-4601(1998)30:10<745::AidKin7>3.0.Co;2-V, 1998.

Becker, K. H., Brockmann, K. J., and Bechara, J.: Production of hydrogen peroxide in forest air by reaction of ozone with terpenes, Nature, 346, 256-268, https://doi.org/10.1038/346256a0, 1990.

Becker, K. H., Bechara, J., and Brockmann, K. J.: Studies on the formation of $\mathrm{H}_{2} \mathrm{O}_{2}$ in the ozonolysis of alkenes, Atmos. Environ. Part A, 27, 57-61, https://doi.org/10.1016/0960-1686(93)90070F, 1993.

Berndt, T., Böge, O., and Stratmann, F.: Gas-phase ozonolysis of $\alpha$-pinene: gaseous products and particle formation, Atmos. Environ., 37, 3933-3945, https://doi.org/10.1016/S13522310(03)00501-6, 2003.

Bonn, B., Kuhlmann, R. V., and Lawrence, M. G.: High contribution of biogenic hydroperoxides to secondary organic aerosol formation, Geophys. Res. Lett., 31, L10108, https://doi.org/10.1029/2003GL019172, 2004. 
Calogirou, A., Larsen, B. R., and Kotzias, D.: Gas-phase terpene oxidation products: a review, Atmos. Environ., 33, 1423-1439, https://doi.org/10.1016/S1352-2310(98)00277-5, 1999.

Calvert, J. G., Lazrus, A., Kok, G. L., Heikes, B. G., Walega, J. G., Lind, J., and Cantrell, C. A.: Chemical mechanisms of acid generation in the troposphere, Nature, 317, 27-35, https://doi.org/10.1038/317027a0, 1985.

Chen, L., Wang, W. L., Wang, W. N., Liu, Y. L., Liu, F. Y., Liu, N., and Wang, B. Z.: Water-catalyzed decomposition of the simplest Criegee intermediate $\mathrm{CH}_{2} \mathrm{OO}$, Theor. Chem. Acc., 135, 131, https://doi.org/10.1007/s00214-016-1894-9, 2016.

Chen, X., Hopke, P. K., and Carter, W. P. L.: Secondary organic aerosol from ozonolysis of biogenic volatile organic compounds: chamber studies of particle and reactive oxygen species formation, Environ. Sci. Technol., 45, 276-282, https://doi.org/10.1021/es102166c, 2011.

Chen, Z. M., Wang, H. L., Zhu, L. H., Wang, C. X., Jie, C. Y., and Hua, W.: Aqueous-phase ozonolysis of methacrolein and methyl vinyl ketone: a potentially important source of atmospheric aqueous oxidants, Atmos. Chem. Phys., 8, 2255-2265, https://doi.org/10.5194/acp-8-2255-2008, 2008.

Chew, A. A. and Atkinson, R.: $\mathrm{OH}$ radical formation yields from the gas-phase reactions of $\mathrm{O}_{3}$ with alkenes and monoterpenes, J. Geophys. Res., 101, 28649-28653, https://doi.org/10.1029/96JD02722, 1996.

Clausen, P. A., Wilkins, C. K., Wolkoff, P., and Nielsen, G. D.: Chemical and biological evaluation of a reaction mixture of R-(+)-limonene/ozone: Formation of strong airway irritants, Environ. Int., 26, 511-522, https://doi.org/10.1016/S01604120(01)00035-6, 2001.

Cocker, D. R., Flagan, R. C., and Seinfeld, J. H.: Stateof-the-art chamber facility for studying atmospheric aerosol chemistry, Environ. Sci. Technol., 35, 2594-2601, https://doi.org/10.1021/es0019169, 2001.

Corrigan, A. L., Hanley, S. W., and Hann, D. O. D.: Uptake of glyoxal by organic and inorganic aerosol, Environ. Sci. Technol., 42, 4428-4433, https://doi.org/10.1021/es7032394, 2008.

Crehuet, R., Anglada, J. M., and Bofill, J. M.: Tropospheric formation of hydroxymethyl hydroperoxide, formic acid, $\mathrm{H}_{2} \mathrm{O}_{2}$, and $\mathrm{OH}$ from carbonyl oxide in the presence of water vapor: A theoretical study of the reaction mechanism, Chem. Eur. J., 7, 2227-2235, https://doi.org/10.1002/15213765(20010518)7:10<2227::AID-CHEM2227>3.0.CO;2-O, 2001

Cremer, D., Gauss, J., Kraka, E., Stanton, J. F., and Bartlett, R. J.: A CCSD (T) investigation of carbonyl oxide and dioxirane. Equilibrium geometries, dipole moments, infrared spectra, heats of formation and isomerization energies, Chem. Phys. Lett., 209, 547-556, https://doi.org/10.1016/0009-2614(93)80131-8, 1993.

Criegee, R.: Mechanism of ozonolysis, Angew. Chem. Int. Edit., 14, 745-752, https://doi.org/10.1002/anie.197507451, 1975.

Crounse, J. D., Mckinney, K. A., Kwan, A. J., and Wennberg, P. O.: Measurement of gas-phase hydroperoxides by chemical ionization mass spectrometry, Anal. Chem., 78, 6726-6732, https://doi.org/10.1021/ac0604235, 2006.

Docherty, K. S. and Ziemann, P. J.: Effects of stabilized Criegee intermediate and $\mathrm{OH}$ radical scavengers on aerosol formation from reactions of $\beta$-pinene with $\mathrm{O}_{3}$, Aerosol Sci. Technol., 37, 877891, https://doi.org/10.1080/02786820300930, 2003.
Docherty, K. S., Wu, W., Lim, Y. B., and Ziemann, P. J.: Contributions of organic peroxides to secondary aerosol formed from reactions of monoterpenes with $\mathrm{O}_{3}$, Environ. Sci. Technol., 39, 4049-4059, https://doi.org/10.1021/es050228s, 2005.

Drozd, G. T., Kurén, T., Donahue, N. M., and Lester, M. I.: Unimolecular decay of the dimethyl-substituted Criegee intermediate in alkene ozonolysis: decay time scales and the importance of tunneling, J. Phys. Chem. A, 121, 6036-6045, https://doi.org/10.1021/acs.jpca.7b05495, 2017.

Ervens, B., Turpin, B. J., and Weber, R. J.: Secondary organic aerosol formation in cloud droplets and aqueous particles (aqSOA): a review of laboratory, field and model studies, Atmos. Chem. Phys., 11, 11069-11102, https://doi.org/10.5194/acp-1111069-2011, 2011.

Fellin, P. and Otson, R.: Assessment of the influence of climatic factors on concentration levels of volatile organic compounds (VOCs) in canadian homes, Atmos. Environ., 28, 3581-3586, https://doi.org/10.1016/1352-2310(94)00204-X, 1994.

Fenske, J. D., Hasson, A. S., Ho, A. W., and Paulson, S. E.: Measurement of absolute unimolecular and bimolecular rate constants for $\mathrm{CH}_{3} \mathrm{CHOO}$ generated by the trans-2-butene reaction with ozone in the gas phase, J. Phys. Chem. A, 104, 9921-9932, https://doi.org/10.1021/jp0016636, 2000.

Fischer, R. and Maier, O.: Interrelation of oxidative stress and inflammation in neurodegenerative disease: role of TNF, Oxid. Med. Cell Longev., 2015, 610813, https://doi.org/10.1155/2015/610813, 2015.

Forester, C. D. and Wells, J. R.: Hydroxyl radical yields from reactions of terpene mixtures with ozone, Indoor Air, 21, 400-409, https://doi.org/10.1111/j.1600-0668.2011.00718.x, 2011.

Gäb, S., Hellpointner, E., Turner, W. V., and Koŕte, F.: Hydroxymethyl hydroperoxide and bis(hydroxymethyl) peroxide from gas-phase ozonolysis of naturally occurring alkenes, Nature, 316, 535-536, https://doi.org/10.1038/316535a0, 1985.

Glasius, M., Lahaniati, M., Calogirou, A., Di Bella, D., Jensen, N. R., Hjorth, J., Kotzias, D., and Larsen, B. R.: Carboxylic acids in secondary aerosols from oxidation of cyclic monoterpenes by ozone, Environ. Sci. Technol., 34, 1001-1010, https://doi.org/10.1021/es990445r, 2000.

Griffin, R. J., Cocker, D. R., Seinfeld, J. H., and Dabdub, D.: Estimate of global atmospheric organic aerosol from oxidation of biogenic hydrocarbons, Geophys. Res. Lett., 26, 2721-2724, https://doi.org/10.1029/1999GL900476, 1999.

Grosjean, D., Williams, E. L., and Seinfeld, J. H.: Atmospheric oxidation of selected terpenes and related carbonyls: gas-phase carbonyl products, Environ. Sci. Technol., 26, 1526-1533, https://doi.org/10.1021/es00032a005, 1992.

Grosjean, D., Williams, E. L., Grosjean, E., Andino, J. M., and Seinfeld, J. H.: Atmospheric oxidation of biogenic hydrocarbons: reaction of ozone with $\beta$-pinene, d-limonene, and trans-caryophyllene, Environ. Sci. Technol., 27, 2754-2758, https://doi.org/10.1021/es00049a014, 1993.

Grossmann, D., Moortgat, G. K., Kibler, M., Schlomski, S., Bachmann, K., Alicke, B., Geyer, A., Platt, U., Hammer, M. U., Vogel, B., Mihelcic, D., Hofzumahaus, A., Holland, F., and Volz-Thomas, A.: Hydrogen peroxide, organic peroxides, carbonyl compounds, and organic acids measured at Pabstthum during BERLIOZ, J. Geophys. Res., 108, 8250, https://doi.org/10.1029/2001JD001096, 2003. 
Groß, C. B. M., Dillon, T. J., Schuster, G., Lelieveld, J., and Crowley, J. N.: Direct kinetic study of $\mathrm{OH}$ and $\mathrm{O}_{3}$ formation in the reaction $\mathrm{CH}_{3} \mathrm{C}(\mathrm{O}) \mathrm{O}_{2}$ with $\mathrm{HO}_{2}$, J. Phys. Chem. A, 118, 974985, https://doi.org/10.1021/jp412380z, 2014.

Guenther, A., Hewitt, C. N., Erickson, D., Fall, R., Geron, C., Graedel, T., Harley, P., Klinger, L., Lerdau, M., Mckay, W. A., Pierce, T., Scholes, B., Steinbrecher, R., Tallamraju, R., Taylor, J., and Zimmerman, P.: A global model of natural volatile organic compound emissions, J. Geophys. Res., 100, 8873-8892, https://doi.org/10.1029/94JD02950, 1995.

Gupta, R. K., Patel, A. K., Shah, N., Choudhary, A. K., Jha, U. K., Yadav, U. C., Gupta, P. K., and Pakuwal, U.: Oxidative stress and antioxidants in disease and Cancer: a review, Asian Pac. J. Cancer P., 15, 4405-4409, https://doi.org/10.7314/APJCP.2014.15.11.4405, 2014.

Gutbrod, R., Schindler, R. N., Kraka, E., and Cremer, D.: Formation of $\mathrm{OH}$ radicals in the gas phase ozonolysis of alkenes: the unexpected role of carbonyl oxides, Chem. Phys. Lett., 252, 221-229, https://doi.org/10.1016/0009-2614(96)00126-1, 1996.

Gutbrod, R., Kraka, E., Schindler, R. N., and Cremer, D.: Kinetic and theoretical investigation of the gas-phase ozonolysis of isoprene: Carbonyl oxides as an important source for $\mathrm{OH}$ radicals in the atmosphere, J. Am. Chem. Soc., 119, 7330-7342, https://doi.org/10.1021/ja970050c, 1997.

Hasson, A. S., Orzechowska, G., and Paulson, S. E.: Production of stabilized Criegee intermediates and peroxides in the gas phase ozonolysis of alkenes: 1 . Ethene, trans-2-butene, and 2,3-dimethyl-2-butene, J. Geophys. Res., 106, 34131-34142, https://doi.org/10.1029/2001JD000597, 2001a.

Hasson, A. S., Ho, A. W., Kuwata, K. T., and Paulson, S. E.: Production of stabilized Criegee intermediates and peroxides in the gas phase ozonolysis of alkenes: 2. Asymmetric and biogenic alkenes, J. Geophys. Res., 106, 34143-34153, https://doi.org/10.1029/2001JD000598, 2001b.

Hasson, A. S., Chung, M. Y., Kuwata, K. T., Converse, A. D., Krohn, D., and Paulson, S. E.: Reaction of Criegee intermediates with water vapor - an additional source of $\mathrm{OH}$ radicals in alkene ozonolysis, J. Phys. Chem. A, 107, 6176-6182, https://doi.org/10.1021/jp0346007, 2003.

Hastings, W. P., Koehler, C. A., Bailey, E. L., and Haan, D. O. D.: Secondary organic aerosol formation by glyoxal hydration and oligomer formation: Humidity effects and equilibrium shifts during analysis, Environ. Sci. Technol., 39, 8728-8735, https://doi.org/10.1021/es0504461, 2005.

Healy, R. M., Wenger, J. C., Metzger, A., Duplissy, J., Kalberer, M., and Dommen, J.: Gas/particle partitioning of carbonyls in the photooxidation of isoprene and 1,3,5-trimethylbenzene, Atmos. Chem. Phys., 8, 3215-3230, https://doi.org/10.5194/acp-8-32152008, 2008.

Healy, R. M., Temime, B., Kuprovskyte, K., and Wenger, J. C.: Effect of relative humidity on gas/particle partitioning and aerosol mass yield in the photooxidation of p-xylene, Environ. Sci. Technol., 43, 1884-1889, https://doi.org/10.1021/es802404z, 2009.

Heaton, K. J., Dreyfus, M. A., Wang, S. Y., and Johnston, M. V.: Oligomers in the early stage of biogenic secondary organic aerosol formation and growth, Environ. Sci. Technol., 41, 61296136, https://doi.org/10.1021/es070314n, 2007.

Henry, K. M. and Donahue, N. M.: Effect of the OH radical scavenger hydrogen peroxide on secondary organic aerosol formation from $\alpha$-pinene ozonolysis, Aerosol Sci. Technol., 45, 696-700, https://doi.org/10.1080/02786826.2011.552926, 2011.

Herrmann, F., Winterhalter, R., Moortgat, G. K., and Williams, J.: Hydroxyl radical $(\mathrm{OH})$ yields from the ozonolysis of both double bonds for five monoterpenes, Atmos. Environ., 44, 3458-3464, https://doi.org/10.1016/j.atmosenv.2010.05.011, 2010.

Hoffmann, T., Odum, J. R., Bowman, F., Collins, D., Klockow, D., Flagan, R. C., and Seinfeld, J. H.: Formation of organic aerosols from the oxidation of biogenic hydrocarbons, J. Atmos. Chem., 26, 189-222, https://doi.org/10.1023/A:1005734301837, 1997.

Hohaus, T., Gensch, I., Kimmel, J., Worsnop, D. R., and Kiendler-Scharr, A.: Experimental determination of the partitioning coefficient of $\beta$-pinene oxidation products in SOAs, Phys. Chem. Chem. Phys., 17, 14796-14804, https://doi.org/10.1039/c5cp01608h, 2015.

Hua, W., Chen, Z. M., Jie, C. Y., Kondo, Y., Hofzumahaus, A., Takegawa, N., Chang, C. C., Lu, K. D., Miyazaki, Y., Kita, K., Wang, H. L., Zhang, Y. H., and Hu, M.: Atmospheric hydrogen peroxide and organic hydroperoxides during PRIDE-PRD'06, China: their concentration, formation mechanism and contribution to secondary aerosols, Atmos. Chem. Phys., 8, 6755-6773, https://doi.org/10.5194/acp-8-6755-2008, 2008.

Huang, D., Chen, Z. M., Zhao, Y., and Liang, H.: Newly observed peroxides and the water effect on the formation and removal of hydroxyalkyl hydroperoxides in the ozonolysis of isoprene, Atmos. Chem. Phys., 13, 5671-5683, https://doi.org/10.5194/acp13-5671-2013, 2013.

Huang, H. L., Chao, W., and Lin, J. J. M.: Kinetics of a Criegee intermediate that would survive high humidity and may oxidize atmospheric $\mathrm{SO}_{2}$, P. Natl. Acad. Sci., 112, 10857-10862, https://doi.org/10.1073/pnas.1513149112, 2015.

Jenkin, M. E.: Modelling the formation and composition of secondary organic aerosol from $\alpha$ - and $\beta$-pinene ozonolysis using MCM v3, Atmos. Chem. Phys., 4, 1741-1757, https://doi.org/10.5194/acp-4-1741-2004, 2004.

Jiang, L., Lan, R., Xu, Y. S., Zhang, W. J., and Yang, W.: Reaction of stabilized Criegee intermediates from ozonolysis of limonene with water: Ab Initio and DFT study, Int. J. Mol. Sci., 14, 57845805, https://doi.org/10.3390/ijms14035784, 2013.

Jonsson, A. M., Hallquist, M., and Ljungström, E.: Impact of humidity on the ozone initiated oxidation of limonene, ${ }^{3}$. carene, and $\alpha$-pinene, Environ. Sci. Technol., 40, 188-194, https://doi.org/10.1021/es051163w, 2006.

Jonsson, A. M., Hallquist, M., and Ljungström, E.: Influence of $\mathrm{OH}$ scavenger on the water effect on secondary organic aerosol formation from ozonolysis of limonene, 3 . carene, and $\alpha$-pinene, Environ. Sci. Technol., 42, 5938-5944, https://doi.org/10.1021/es702508y, 2008a.

Jonsson, Å. M., Hallquist, M., and Ljungström, E.: The effect of temperature and water on secondary organic aerosol formation from ozonolysis of limonene, $\delta^{3}$-carene and $\alpha$-pinene, Atmos. Chem. Phys., 8, 6541-6549, https://doi.org/10.5194/acp-8-65412008, 2008b.

Keywood, M. D., Kroll, J. H., Varutbangkul, V., Bahreini, R., Flagan, R. C., and Seinfeld, J. H.: Secondary organic aerosol formation from cyclohexene ozonolysis: Effect of $\mathrm{OH}$ scavenger and the role of radical chemistry, Environ. Sci. Technol., 38, 33433350, https://doi.org/10.1021/es049725j, 2004. 
Khan, M. A. H., Cooke, M. C., Utembe, S. R., Xiao, P., Morris, W. C., Derwent, R. G., Archibald, A. T., Jenkin, M. E., Percival, C. J., and Shallcross, D. E.: The global budgets of organic hydroperoxides for present and pre-industrial scenarios, Atmos. Environ., 110, 65-74, https://doi.org/10.1016/j.atmosenv.2015.03.045, 2015.

Kroll, J. H. and Seinfeld, J. H.: Chemistry of secondary organic aerosol: Formation and evolution of low-volatility organics in the atmosphere, Atmos. Environ., 42, 3593-3624, https://doi.org/10.1016/j.atmosenv.2008.01.003, 2008.

Kroll, J. H., Clarke, J. S., Donahue, N. M., Anderson, J. G., and Demerjian, K. L.: Mechanism of $\mathrm{HO}_{x}$ formation in the gas-phase ozone-alkene reaction. 1. Direct, pressure-dependent measurements of prompt OH yields, J. Phys. Chem. A, 105, 1554-1560, https://doi.org/10.1021/jp002121r, 2001a.

Kroll, J. H., Sahay, S. R., Anderson, J. G., Demerjian, K. L., and Donahue, N. M.: Mechanism of $\mathrm{HO}_{x}$ formation in the gas-phase ozone-alkene reaction. 2. Prompt versus thermal dissociation of carbonyl oxides to form OH, J. Phys. Chem. A, 105, 4446-4457, https://doi.org/10.1021/jp004136v, 2001 b.

Kroll, J. H., Ng, N. L., Murphy, S. M., Varutbangkul, V., Flagan, R. C., and Seinfeld, J. H.: Chamber studies of secondary organic aerosol growth by reactive uptake of simple carbonyl compounds, J. Geophys. Res., 110, D23207, https://doi.org/10.1029/2005JD006004, 2005.

Kumar, M., Busch, D. H., Subramaniam, B., and Thompson, W. H.: Role of tunable acid catalysis in decomposition of $\alpha$ hydroxyalkyl hydroperoxides and mechanistic implications for tropospheric chemistry, J. Phys. Chem. A, 118, 9701-9711, https://doi.org/10.1021/jp505100x, 2014.

Lamb, B., Gay, D., Westberg, H., and Pierce, T.: A biogenic hydrocarbon emission inventory for the U.S.A. using a simple forest canopy model, Atmos. Environ. Part A, 27, 1673-1690, https://doi.org/10.1016/0960-1686(93)90230-V, 1993.

Lane, T. E., Donahue, N. M., and Pandis, S. N.: Simulating secondary organic aerosol formation using the volatility basisset approach in a chemical transport model, Atmos. Environ., 42, 7439-7451, https://doi.org/10.1016/j.atmosenv.2008.06.026, 2008.

Lee, A., Goldstein, A. H., Keywood, M. D., Gao, S., Varutbangkul, V., Bahreini, R., Ng, N. L., Flagan, R. C., and Seinfeld, J. H.: Gas-phase products and secondary aerosol yields from the ozonolysis of ten different terpenes, J. Geophys. Res., 111, D07302, https://doi.org/10.1029/2005JD006437, 2006.

Lee, M. H., Heikes, B. G., and O'Sullivan, D. W.: Hydrogen peroxide and organic hydroperoxide in the troposphere: a review, Atmos. Environ., 34, 3475-3494, https://doi.org/10.1016/S13522310(99)00432-X, 2000.

Leungsakul, S., Jaoui, M., and Kamens, R. M.: Kinetic mechanism for predicting secondary organic aerosol formation from the reaction of d-limonene with ozone, Environ. Sci. Technol., 39, 9583-9594, https://doi.org/10.1021/es0492687, 2005.

Li, H., Chen, Z., Huang, L., and Huang, D.: Organic peroxides' gasparticle partitioning and rapid heterogeneous decomposition on secondary organic aerosol, Atmos. Chem. Phys., 16, 1837-1848, https://doi.org/10.5194/acp-16-1837-2016, 2016.

Liang, H., Chen, Z. M., Huang, D., Zhao, Y., and Li, Z. Y.: Impacts of aerosols on the chemistry of atmospheric trace gases: a case study of peroxides and $\mathrm{HO}_{2}$ radicals, Atmos. Chem.
Phys., 13, 11259-11276, https://doi.org/10.5194/acp-13-112592013, 2013.

Liang, H., Chen, Z. M., Huang, D., Wu, Q. Q., and Huang, L. B.: Understanding atmospheric peroxyformic acid chemistry: observation, modeling and implication, Atmos. Chem. Phys. Discuss., 15, 2055-2084, https://doi.org/10.5194/acpd-15-20552015, 2015.

Lightfoot, P. D., Cox, R. A., Crowley, J. N., Destriau, M., Hayman, G. D., Jenkin, M. E., Moortgat, G. K., and Zabel, F.: Organic peroxy radicals: Kinetics, spectroscopy and tropospheric chemistry, Atmos. Environ. Part A, 26, 1805-1961, https://doi.org/10.1016/0960-1686(92)90423-I, 1992.

Lin, L. C., Chang, H. T., Chang, C. H., Chao, W., Smith, M. C., Chang, C. H., Lin, J. J. M., and Takahashi, K.: Competition between $\mathrm{H}_{2} \mathrm{O}$ and $\left(\mathrm{H}_{2} \mathrm{O}\right)_{2}$ reactions with $\mathrm{CH}_{2} \mathrm{OO} / \mathrm{CH}_{3} \mathrm{CHOO}$, Phys. Chem. Chem. Phys., 18, 45574568, https://doi.org/10.1039/c5cp06446e, 2016.

Long, B., Bao, J. L., and Truhlar, D. G.: Unimolecular reaction of acetone oxide and its reaction with water in the atmosphere, P. Natl. Acad. Sci. USA, 115, 6135-6140, https://doi.org/10.1073/pnas.1804453115, 2018.

Ma, Y., Russell, A. T., and Marston, G.: Mechanisms for the formation of secondary organic aerosol components from the gasphase ozonolysis of $\alpha$-pinene, Phys. Chem. Chem. Phys., 10, 4294-4312, https://doi.org/10.1039/b803283a, 2008.

Mauldin, R. L., Berndt, T., Sipilä, M., Paasonen, P., Petäjä, T., Kim, S., Kurtén, T., Stratmann, F., Kerminen, V. M., and Kulmala, M.: A new atmospherically relevant oxidant of sulphur dioxide, Nature, 488, 193-196, https://doi.org/10.1038/nature11278, 2012.

Mcneill, V. F., Woo, J. L., Kim, D. D., Schwier, A. N., Wannell, N. J., Sumner, A. J., and Barakat, J. M.: Aqueous-phase secondary organic aerosol and organosulfate formation in atmospheric aerosols: A modeling study, Environ. Sci. Technol., 46, 8075-8081, https://doi.org/10.1021/es3002986, 2012.

Mertes, P., Pfaffenberger, L., Dommen, J., Kalberer, M., and Baltensperger, U.: Development of a sensitive long path absorption photometer to quantify peroxides in aerosol particles (Peroxide-LOPAP), Atmos. Meas. Tech., 5, 2339-2348, https://doi.org/10.5194/amt-5-2339-2012, 2012.

Möller, D.: Atmospheric hydrogen peroxide: Evidence for aqueousphase formation from a historic perspective and a one-year measurement campaign, Atmos. Environ., 43, 5923-5936, https://doi.org/10.1016/j.atmosenv.2009.08.013, 2009.

Moller, B., Rarey, J., and Ramjugernath, D.: Estimation of the vapour pressure of non-electrolyte organic compounds via group contributions and group interactions, J. Mol. Liq., 143, 52-63, https://doi.org/10.1016/j.molliq.2008.04.020, 2008.

Mutzel, A., Rodigast, M., Iinuma, Y., Böge, O., and Herrmann, H.: An improved method for the quantification of SOA bound peroxides, Atmos. Environ., 67, 365-369, https://doi.org/10.1016/j.atmosenv.2012.11.012, 2013.

Ng, N. L., Kroll, J. H., Keywood, M. D., Bahreini, R., Varutbangkul, V., Flagan, R. C., Seinfeld, J. H., Lee, A., and Goldstein, A. H.: Contribution of first- versus second-generation products to secondary organic aerosols formed in the oxidation of biogenic hydrocarbons, Environ. Sci. Technol., 40, 2283-2297, https://doi.org/10.1021/es052269u, 2006.

Nguyen, T. B., Bateman, A. P., Bones, D. L., Nizkorodov, S. A., Laskin, J., and Laskin, A.: High-resolution mass spec- 
trometry analysis of secondary organic aerosol generated by ozonolysis of isoprene, Atmos. Environ., 44, 1032-1042, https://doi.org/10.1016/j.atmosenv.2009.12.019, 2010.

Odum, J. R., Hoffmann, T., Bowman, F., Collins, D., Flagan, R. C., and Seinfeld, J. H.: Gas/particle partitioning and secondary organic aerosol yields, Environ. Sci. Technol., 30, 2580-2585, https://doi.org/10.1021/es950943+, 1996.

Ortiz, R., Shimada, S., Sekiguchi, K., Wang, Q., and Sakamoto, K.: Measurements of changes in the atmospheric partitioning of bifunctional carbonyls near a road in a suburban area, Atmos. Environ., 81, 554-560, https://doi.org/10.1016/j.atmosenv.2013.09.045, 2013.

Pankow, J. F.: An absorption model of the gas/aerosol partitioning involved in the formation of secondary organic aerosol, Atmos. Environ., 28, 189-193, https://doi.org/10.1016/13522310(94)90094-9, 1994.

Pankow, J. F. and Bidleman, T. F.: Interdependence of the slopes and intercepts from log-log correlations of measured gasparticle partitioning and vapor pressure 1. theory and analysis of available data, Atmos. Environ. Part A, 26, 1071-1080, https://doi.org/10.1016/0960-1686(92)90039-N, 1992.

Pathak, R. K., Salo, K., Emanuelsson, E. U., Cai, C., Lutz, A., Hallquist, A. M., and Hallquist, M.: Influence of ozone and radical chemistry on limonene organic aerosol production and thermal characteristics, Environ. Sci. Technol., 46, 11660-11669, https://doi.org/10.1021/es301750r, 2012.

Peña, R. M., García, S., Herrero, C., and Lucas, T.: Measurements and analysis of hydrogen peroxide rainwater levels in a Northwest region of Spain, Atmos. Environ., 35, 209-219, https://doi.org/10.1016/S1352-2310(00)00246-6, 2001.

Penkett, S. A., Jones, B. M. R., Brich, K. A., and Eggleton, A. E. J.: The importance of atmospheric ozone and hydrogen peroxide in oxidising sulphur dioxide in cloud and rainwater, Atmos. Environ., 13, 123-137, https://doi.org/10.1016/0004-6981(79)902518, 1979.

Presto, A. A. and Donahue, N. M.: Ozonolysis fragment quenching by nitrate formation: The pressure dependence of prompt OH radical formation, J. Phys. Chem. A, 108, 9096-9104, https://doi.org/10.1021/jp047162s, 2004.

Presto, A. A., Hartz, K. E. H., and Donahue, N. M.: Secondary organic aerosol production from terpene ozonolysis. 1. Effect of UV radiation, Environ. Sci. Technol., 39, 7036-7045, https://doi.org/10.1021/es050174m, 2005.

Prinn, R. G.: The cleansing capacity of the atmosphere, Annu. Rev. Environ. Resour., 28, 29-57, https://doi.org/10.1146/annurev.energy.28.011503.163425, 2003.

Pye, H. O. T. and Seinfeld, J. H.: A global perspective on aerosol from low-volatility organic compounds, Atmos. Chem. Phys., 10, 4377-4401, https://doi.org/10.5194/acp-10-4377-2010, 2010.

Sakamoto, Y., Yajima, R., Inomata, S., and Hirokawa, J.: Water vapour effects on secondary organic aerosol formation in isoprene ozonolysis, Phys. Chem. Chem. Phys., 19, 3165-3175, https://doi.org/10.1039/c6cp04521a, 2017.

Sauer, F., Schuster, G., Schäfer, C., and Moortgat, G. K.: Determination of $\mathrm{H}_{2} \mathrm{O}_{2}$ and organic peroxides in cloud- and rain-water on the Kleiner Feldberg during FELDEX, Geophys. Res. Lett., 23, 2605-2608, https://doi.org/10.1029/96GL02475, 1996.
Sauer, F., Limbach, S., and Moortgat, G. K.: Measurements of hydrogen peroxide and individual organic peroxides in the marine troposphere, Atmos. Environ., 31, 1173-1184, https://doi.org/10.1016/S1352-2310(96)00289-0, 1997.

Sauer, F., Schäfer, C., Neeb, P., Horie, O., and Moortgat, G. K.: Formation of hydrogen peroxide in the ozonolysis of isoprene and simple alkenes under humid conditions, Atmos. Environ., 33, 229-241, https://doi.org/10.1016/S1352-2310(98)00152-6, 1999.

Seifert, B., Mailahn, W., Schulz, C., and Ullrich, D.: Seasonal variation of concentrations of volatile organic compounds in selected German homes, Environ. Int., 15, 397-408, https://doi.org/10.1016/0160-4120(89)90054-8, 1989.

Sheps, L., Scully, A. M., and Au, K.: UV absorption probing of the conformer-dependent reactivity of a Criegee intermediate $\mathrm{CH}_{3} \mathrm{CHOO}$, Phys. Chem. Chem. Phys., 16, 26701-26706, https://doi.org/10.1039/c4cp04408h, 2014.

Shu, Y. H. and Atkinson, R.: Rate constants for the gasphase reactions of $\mathrm{O}_{3}$ with a series of terpenes and $\mathrm{OH}$ radical formation from the $\mathrm{O}_{3}$ reactions with sesquiterpenes at 296 $\pm 2 \mathrm{~K}$, Int. J. Chem. Kinet., 26, 1193-1205, https://doi.org/10.1002/kin.550261207, 1994.

Sindelarova, K., Granier, C., Bouarar, I., Guenther, A., Tilmes, S., Stavrakou, T., Müller, J.-F., Kuhn, U., Stefani, P., and Knorr, W.: Global data set of biogenic VOC emissions calculated by the MEGAN model over the last 30 years, Atmos. Chem. Phys., 14, 9317-9341, https://doi.org/10.5194/acp-14-9317-2014, 2014.

Sipilä, M., Jokinen, T., Berndt, T., Richters, S., Makkonen, R., Donahue, N. M., Mauldin III, R. L., Kurtén, T., Paasonen, P., Sarnela, N., Ehn, M., Junninen, H., Rissanen, M. P., Thornton, J., Stratmann, F., Herrmann, H., Worsnop, D. R., Kulmala, M., Kerminen, V.-M., and Petäjä, T.: Reactivity of stabilized Criegee intermediates (sCIs) from isoprene and monoterpene ozonolysis toward SO2 and organic acids, Atmos. Chem. Phys., 14, 1214312153, https://doi.org/10.5194/acp-14-12143-2014, 2014.

Stroud, C., Makar, P., Karl, T., Guenther, A., Geron, C., Turnipseed, A., Nemitz, E., Baker, B., Potosnak, M., and Fuentes, J. D.: Role of canopy-scale photochemistry in modifying biogenicatmosphere exchange of reactive terpene species: Results from the CELTIC field study, J. Geophys. Res., 110, D17303, https://doi.org/10.1029/2005JD005775, 2005.

Surratt, J. D., Murphy, S. M., Kroll, J. H., Ng, N. L., Hildebrandt, L., Sorooshian, A., Szmigielski, R., Vermeylen, R., Maenhaut, W., Claeys, M., Flagan, R. C., and Seinfeld, J. H.: Chemical composition of secondary organic aerosol formed from the photooxidation of isoprene, J. Phys. Chem. A, 110, 9665-9690, https://doi.org/10.1021/jp061734m, 2006.

Taatjes, C. A., Welz, O., Eskola, A. J., Savee, J. D., Scheer, A. M., Shallcross, D. E., Rotavera, B., Lee, E. P. F., Dyke, J. M., Mok, D. K. W., Osborn, D. L., and Percival, C. J.: Direct measurements of conformer-dependent reactivity of the Criegee intermediate $\mathrm{CH}_{3} \mathrm{CHOO}$, Science, 340, 177-180, https://doi.org/10.1126/science.1234689, 2013.

Tillmann, R., Hallquist, M., Jonsson, ̊. M., Kiendler-Scharr, A., Saathoff, H., Iinuma, Y., and Mentel, Th. F.: Influence of relative humidity and temperature on the production of pinonaldehyde and $\mathrm{OH}$ radicals from the ozonolysis of $\alpha$-pinene, Atmos. Chem. Phys., 10, 7057-7072, https://doi.org/10.5194/acp10-7057-2010, 2010. 
Tobias, H. J. and Ziemann, P. J.: Thermal desorption mass spectrometric analysis of organic aerosol formed from reactions of aerosol formed from reactions of 1-tetradecene and $\mathrm{O}_{3}$ in the presence of alcohols and carboxylic acids, Environ. Sci. Technol., 34, 2105-2115, https://doi.org/10.1021/es9907156, 2000.

Tobias, H. J., Docherty, K. S., Beving, D. E., and Ziemann, P. J.: Effect of relative humidity on the chemical composition of secondary organic aerosol formed from reactions of 1tetradecene and $\mathrm{O}_{3}$, Environ. Sci. Technol., 34, 2116-2125, https://doi.org/10.1021/es991057s, 2000.

Toda, K., Yunoki, S., Yanaga, A., Takeuchi, M., Ohira, S., Dasgupta, P. K., Formaldehyde content of atmospheric aerosol, Environ. Sci. Technol., 48, 6636-6643, https://doi.org/10.1021/es500590e, 2014.

Tyndall, G. S., Cox, R. A., Granier, C., Lesclaux, R., Moortgat, G. K., Pilling, M. J., Ravishankara, A. R., and Wallington, T. J.: Atmospheric chemistry of small organic peroxy radicals, J. Geophys. Res., 106, 12157-12182, https://doi.org/10.1029/2000JD900746, 2001.

Verma, V., Ning, Z., Cho, A. K., Schauer, J. J., Shafer, M. M., and Sioutas, C.: Redox activity of urban quasi-ultrafine particles from primary and secondary sources, Atmos. Environ., 43, 63606368, https://doi.org/10.1016/j.atmosenv.2009.09.019, 2009.

Volkamer, R., Martini, F. S., Molina, L. T., Salcedo, D., Jimenez, J. L., and Molina, M. J.: A missing sink for gas-phase glyoxal in Mexico City: Formation of secondary organic aerosol, Geophys. Res. Lett., 34, L19807, https://doi.org/10.1029/2007GL030752, 2007.

Wallington, T. J., Dagaut, P., and Kurylo, M. J.: UV absorption cross section kinetics and mechanisms for peroxy radicals in the gas phase, Chem. Rev., 92, 667-710, https://doi.org/10.1021/cr00012a008, 1992.

Wang, H. L., Zhang, X., and Chen, Z. M.: Development of DNPH/HPLC method for the measurement of carbonyl compounds in the aqueous phase: applications to laboratory simulation and field measurement, Environ. Chem., 6, 389-397, https://doi.org/10.1071/EN09057, 2009.

Wang, Y., Kim, H., and Paulson, S. E.: Hydrogen peroxide generation from $\alpha$ - and $\beta$-pinene and toluene secondary organic aerosols, Atmos. Environ., 45, 3149-3156, https://doi.org/10.1016/j.atmosenv.2011.02.060, 2011.

Wegener, R., Brauers, T., Koppmann, R., Bares, S. R., Rohrer, F., Tillmann, R., Wahner, A., Hansel, A., and Wisthaler, A.: Simulation chamber investigation of the reactions of ozone with short-chained alkenes, J. Geophys. Res., 112, D13301, https://doi.org/10.1029/2006JD007531, 2007.

Welz, O., Savee, J. D., Osborn, D. L., Vasu, S. S., Percival, C. J., Shallcross, D. E., and Taatjes, C. A.: Direct kinetic measurements of Criegee intermediate $\left(\mathrm{CH}_{2} \mathrm{OO}\right)$ formed by reaction of $\mathrm{CH}_{2} \mathrm{I}$ with $\mathrm{O}_{2}$, Science, 335, 204-207, https://doi.org/10.1126/science.1213229, 2012.
Welz, O., Eskola, A. J., Sheps, L., Rotavera, B., Savee, J. D., Scheer, A. M., Osborn, D. L., Lowe, D., Booth, A. M., Xiao, P., Khan, M. A. H., Percival, C. J., Shallcross, D. E., and Taatjes, C. A.: Rate coefficients of $\mathrm{C} 1$ and $\mathrm{C} 2$ Criegee intermediate reactions with formic and acetic acid near the collision limit: direct kinetics measurements and atmospheric implications, Angew. Chem. Int. Ed., 53, 4547-4550, https://doi.org/10.1002/anie.201400964, 2014.

Winiberg, F. A. F., Dillon, T. J., Orr, S. C., Groß, C. B. M., Bejan, I., Brumby, C. A., Evans, M. J., Smith, S. C., Heard, D. E., and Seakins, P. W.: Direct measurements of $\mathrm{OH}$ and other product yields from the $\mathrm{HO}_{2}+? \mathrm{CH}_{3} \mathrm{C}(\mathrm{O}) \mathrm{O}_{2}$ reaction, Atmos. Chem. Phys., 16, 4023-4042, https://doi.org/10.5194/acp16-4023-2016, 2016

Winterhalter, R., Neeb, P., Grossmann, D., Kolloff, A., Horie, O., and Moortgat, G.: Products and mechanism of the gas phase reaction of ozone with $\beta$-pinene, J. Atmos. Chem., 35, 165-197, https://doi.org/10.1023/A:1006257800929, 2000.

Wolkoff, P., Clausen, P. A., Wilkins, C. K., and Nielsen, G. D.: Formation of strong airway irritants in terpene/ozone mixtures, Indoor Air, 10, 82-91, https://doi.org/10.1034/j.16000668.2000.010002082.x, 2000.

Wragg, F. P. H., Fuller, S. J., Freshwater, R., Green, D. C., Kelly, F. J., and Kalberer, M.: An automated online instrument to quantify aerosol-bound reactive oxygen species (ROS) for ambient measurement and health-relevant aerosol studies, Atmos. Meas. Tech., 9, 4891-4900, https://doi.org/10.5194/amt-9-4891-2016, 2016.

Yao, L., Ma, Y., Wang, L., Zheng, J., Khalizov, A., Chen, M. D., Zhou, Y. Y., Qi, L., and Cui, F. P.: Role of stabilized Criegee Intermediate in secondary organic aerosol formation from the ozonolysis of $\alpha$-cedrene, Atmos. Environ., 94, 448-457, https://doi.org/10.1016/j.atmosenv.2014.05.063, 2014.

Yu, J. Z., Cocker, D. R., Griffin, R. J., Flagan, R. C., and Seinfeld, J. H.: Gas-phase ozone oxidation of monoterpenes: gaseous and particulate products, J. Atmos. Chem., 34, 207-258, https://doi.org/10.1023/A:1006254930583, 1999.

Zhang, D. and Zhang, R. Y.: Ozonolysis of $\alpha$-pinene and $\beta$ pinene: kinetics and mechanism, J. Chem. Phys., 122, 114308 , https://doi.org/10.1063/1.1862616, 2005.

Zhang, J. Y., Hartz, K. E. H., Pandis, S. N., and Donahue, N. M.: Secondary organic aerosol formation from limonene ozonolysis: homogeneous and heterogeneous influences as a function of $\mathrm{NO}_{x}$, J. Phys. Chem. A, 110, 11053-11063, https://doi.org/10.1021/jp062836f, 2006.

Zhang, X., Chen, Z. M., He, S. Z., Hua, W., Zhao, Y., and Li, J. L.: Peroxyacetic acid in urban and rural atmosphere: concentration, feedback on $\mathrm{PAN}^{-\mathrm{NO}_{x}}$ cycle and implication on radical chemistry, Atmos. Chem. Phys., 10, 737-748, https://doi.org/10.5194/acp-10-737-2010, 2010. 